This is the peer reviewed version of the following article: Mattick, K. , Brennan, N. , Briscoe, S. , Papoutsi, C. and Pearson, M. (2019), Optimising feedback for early career professionals: a scoping review and new framework. Med Educ, 53: 355-368, which has been published in final form at https://doi.org/10.1111/medu.13794. This article may be used for non-commercial purposes in accordance with Wiley Terms and Conditions for Use of Self-Archived Versions.

\title{
Optimising feedback for early career professionals: a scoping review and
}

\section{new framework}

Karen Mattick, ${ }^{1}$ Nicola Brennan, ${ }^{2 *}$ Simon Briscoe, ${ }^{3}$ Chrysanthi Papoutsi, ${ }^{4}$ Mark Pearson. ${ }^{5}$

Affiliations:

1. Centre for Research in Professional Learning, University of Exeter, Exeter, UK

2. Collaboration for the Advancement of Medical Education Research and Assessment,

Plymouth University Peninsula Schools of Medicine and Dentistry, Plymouth, UK

3. Exeter HS\&DR Evidence Synthesis Centre, Institute of Health Research, University of Exeter Medical School, Exeter, UK

4. Nuffield Department of Primary Care Health Sciences, University of Oxford, Oxford, UK

5. Wolfson Palliative Care Research Centre, Hull York Medical School, University of Hull, Hull,

UK

* Corresponding author

Dr. Nicola Brennan

Collaboration for the Advancement of Medical Education Research and Assessment, Plymouth University Peninsula Schools of Medicine and Dentistry, C506 Portland Square, Drake Circus,

Plymouth, Devon, PL4 8AA

Tel: 00 (44) 1752586838

Email: nicola.brennan@plymouth.ac.uk 
This is the peer reviewed version of the following article: Mattick, K. , Brennan, N. , Briscoe, S. , Papoutsi, C. and Pearson, M. (2019), Optimising feedback for early career professionals: a scoping review and new framework. Med Educ, 53: 355-368, which has been published in final form at https://doi.org/10.1111/medu.13794. This article may be used for non-commercial purposes in accordance with Wiley Terms and Conditions for Use of Self-Archived Versions.

\section{Abstract}

Introduction: Meta-analyses have shown that feedback can be a powerful intervention to increase learning and performance but there is significant variability in impact. New trials are adding little to the question of whether feedback interventions are effective, so the focus now is how to optimise the effect. Early career professionals (ECPs) in busy work environments are a particularly important target group. This literature review aimed to synthesise information to support the optimal design of feedback interventions for ECPs.

Methods: We undertook a scoping literature review, using search terms such as 'feedback' and 'effectiveness' in MEDLINE; MEDLINE-in-Process; PsycINFO; CINAHL; Education Research Complete; ERIC; Cochrane Database of Systematic Reviews; Social Science Citation Index; and ASSIA, to identify empirical studies describing feedback interventions in busy workplaces published in English since 1990. We applied inclusion criteria to identify studies for the mapping stage and extracted key data to inform the next stage. We then selected a subset of papers for the framework development stage, which were subjected to a thematic synthesis by three authors leading to a new Feedback Framework and a modified version of Feedback Intervention Theory specifically for ECPs.

Results: Eighty studies were included in the mapping stage, with roughly equal studies from hospital settings and school classrooms, and seventeen papers were included in the framework development stage. The Feedback Framework comprised 3 main categories (Audit, Feedback, and Goal-Setting) and 22 subcategories. The review highlighted the limited empirical research focussing solely on feedback for ECPs, which was surprising given the particular nuances to feedback for ECPs identified through this study.

Discussion: We offer the Feedback Framework to optimise the design of future feedback interventions for Early Career Professionals and encourage future feedback research to move away from generic models and tailor their work to specific target audiences. 
This is the peer reviewed version of the following article: Mattick, K. , Brennan, N. , Briscoe, S. , Papoutsi, C. and Pearson, M. (2019), Optimising feedback for early career professionals: a scoping review and new framework. Med Educ, 53: 355-368, which has been published in final form at https://doi.org/10.1111/medu.13794. This article may be used for non-commercial purposes in accordance with Wiley Terms and Conditions for Use of Self-Archived Versions.

Introduction: Word count (main manuscript): 5,394

Meta-analyses in education have shown that feedback can be a powerful intervention to increase learning and performance (1). In primary and secondary education, feedback has been identified as one of the most impactful education interventions, resulting in an average learning gain of 8 months in every year (2). The importance of feedback has also been recognised in healthcare and healthcare education, with audit and feedback generally leading to small but potentially important improvements in professional practice $(3,4)$. Feedback in both education and healthcare, however, shows significant variability in impact, with some interventions having no impact, or even negative impact $(4,5)$. In other words, whilst feedback can be powerful and effective in certain circumstances, the outcomes are inconsistent. This is perhaps not surprising, given the large number of behaviours and settings to which feedback interventions have been applied and the multiple components of feedback that may be altered.

Research exploring the different components of feedback which contribute to effectiveness also faces challenges. The latest Cochrane systematic review on audit and feedback, undertaken by the Effective Practice and Organisation of Care (EPOC) group (3) synthesised best estimates of effect sizes according to different components of feedback interventions and concluded that feedback may be most effective when health professionals are not performing well to start out with; when the person responsible for the audit and feedback is a supervisor or colleague; when feedback is provided more than once; when feedback is given verbally and in writing; and when it includes clear targets and an action plan. In 2014, Ivers et al. (4) extended this Cochrane review and a cumulative analysis showed that the effect size became stable in 2003 , suggesting that new trials are adding little to the question of whether feedback interventions are effective. As they put it: "At this point the appropriate question is not 'can audit and feedback improve professional practice' but 'how can the effect of audit and 
This is the peer reviewed version of the following article: Mattick, K. , Brennan, N. , Briscoe, S. , Papoutsi, C. and Pearson, M. (2019), Optimising feedback for early career professionals: a scoping review and new framework. Med Educ, 53: 355-368, which has been published in final form at https://doi.org/10.1111/medu.13794. This article may be used for non-commercial purposes in accordance with Wiley Terms and Conditions for Use of Self-Archived Versions.

feedback interventions be optimised?'” (p1538). They conclude that research is now needed to understand the impact of task characteristics, feedback characteristics, recipient characteristics and context on feedback effectiveness (4). From a complex systems perspective (6), these different characteristics are also likely to interact in unforeseen ways, so rich descriptions of the feedback process and its impact (or lack of impact) will be needed. Whereas, the Cochrane reviews have only included RCTs, other types of study designs and theoretical perspectives are now required to explore the professional or organisational processes that may impact substantially on effectiveness and provide greater insights into mechanisms and unintended consequences.

Colquhoun et al. (7) argue that part of the problem is that interventions have typically been designed without underpinning theory from the behavioural and social sciences. This is problematic because theory provides important insights into how change strategies might work and when and why they might not work. Colquhoun et al. (7) analysed randomised controlled trials of audit and feedback and concluded that explicit use of theory in these studies was rare. Colquhoun et al. (8) developed a list of theory-informed hypotheses, based on interviews with theory experts, about how to design more effective audit and feedback interventions. This can inform practical guidance to support those designing feedback interventions (9).

Early career professionals (ECPs), who are transitioning into busy work environments, are a particularly important group of learners. It is increasingly clear that the experiences and needs of those at the beginning of their careers are different from experienced professionals, for example because they may be unfamiliar with the workplace systems and professional norms and may be working within a strong professional hierarchy (10). To date, there is little research that targets early career professionals specifically and we need to know much more 
This is the peer reviewed version of the following article: Mattick, K. , Brennan, N. , Briscoe, S. , Papoutsi, C. and Pearson, M. (2019), Optimising feedback for early career professionals: a scoping review and new framework. Med Educ, 53: 355-368, which has been published in final form at https://doi.org/10.1111/medu.13794. This article may be used for non-commercial purposes in accordance with Wiley Terms and Conditions for Use of Self-Archived Versions.

about how the type of feedback received, intentionally or unintentionally, affects the learning or sense of professional identity of qualified professionals entering the workplace (11). Since feedback is often more effective when baseline performance is low (3), it is likely that the 'return on investment' from a feedback intervention in terms of impact on professional practice would be high as ECPs learn to undertake the tasks required by their new jobs. In addition, retention of early career professionals is problematic in medicine, teaching and beyond, suggesting that additional opportunities to provide support and encouragement are needed. The transition from university to work is challenging in any field but may be particularly daunting in busy environments such as hospital wards and school classrooms, which are what Eraut (12) calls "hot action" contexts where "changing conditions feature prominently" (p258).

Therefore the aim of this scoping review was to bring together information in an easily accessible way to support the optimal design, implementation and reporting of workplacebased feedback interventions for early career professionals. This complements previous research, such as Van der Ridder et al. (13) whose work focusses on undergraduate education and assessments (rather than early career professionals in busy workplace environments and naturally occurring workplace-based measures); and whose primary audience is researchers (rather than feedback intervention designers). Given the complexity of feedback interventions and their variable reported impact, our methodological approach sought to identify literature that provided in-depth accounts of feedback strategies that aimed to change the behaviour of early career professionals, from research involving a wide range of study designs and from different professions. We then developed a Feedback Framework which can be used to optimise the design of future interventions and developed a theory of feedback that was broad enough to accommodate what we had learned about early career professionals. 
This is the peer reviewed version of the following article: Mattick, K. , Brennan, N. , Briscoe, S. , Papoutsi, C. and Pearson, M. (2019), Optimising feedback for early career professionals: a scoping review and new framework. Med Educ, 53: 355-368, which has been published in final form at https://doi.org/10.1111/medu.13794. This article may be used for non-commercial purposes in accordance with Wiley Terms and Conditions for Use of Self-Archived Versions.

\section{Methods:}

\section{Aim / Research Questions:}

The aim of this literature review was to bring together information which can support the optimal design, implementation and reporting of workplace-based feedback interventions for early career professionals (as defined in Table 1).

The research questions were:

- What features of workplace-based feedback interventions are important in changing early career professional behaviours and/or improving workplace outcomes?

- Why are these features important and how might they work for early career professionals?

- Under what specific circumstances are these features potentially most beneficial?

Informed by Arksey and O'Malley's methodological framework, we conducted a scoping review to characterise published research literature relating to a given topic $(14,15)$. We considered a number of educational, psychological and socio-cultural theories to inform our study but ultimately selected Feedback Intervention Theory from organisational and management research, and used their definition of feedback as our starting point (5). Feedback Intervention Theory has five basic arguments: behaviour is regulated by comparisons of feedback to goals or standards; goals or standards are organised hierarchically; attention is limited and therefore only feedback-standard gaps that receive attention actively participate in behaviour regulation; attention is normally directed to a moderate level of the hierarchy; and feedback interventions change the locus of attention and therefore may affect behaviour. 
This is the peer reviewed version of the following article: Mattick, K. , Brennan, N. , Briscoe, S. , Papoutsi, C. and Pearson, M. (2019), Optimising feedback for early career professionals: a scoping review and new framework. Med Educ, 53: 355-368, which has been published in final form at https://doi.org/10.1111/medu.13794. This article may be used for non-commercial purposes in accordance with Wiley Terms and Conditions for Use of Self-Archived Versions.

\section{$\underline{\text { Definitions }}$}

- Feedback: for the purposes of this study, we see feedback as an intervention comprising those "actions taken by (an) external agent(s) to provide information regarding some aspect(s) of one's task performance" (5). Our focus was feedback from workplace measures that related to specific element(s) of authentic practice and which targeted learner behaviours relevant to professional practice and/or clinical workplace outcomes. Assessment feedback was out of scope, unless it met these specific criteria. Feedback on simulated activities was out of scope.

- Workplace settings: this study was interested only in feedback within authentic, busy workplaces settings comparable to a 'hot action' context (12), such as hospital wards or school classrooms.

- Early Career Professional: a graduate who is less than two years into professional practice.

\section{Developing the search to identify studies}

Search terms were identified through background searching in Google and relevant journals, and specificity and sensitivity of free-text (i.e. title and abstract), and indexing (e.g. MeSH) terms explored using Ovid MEDLINE. Combinations of search terms were benchmarked against pre-specified target papers. Our final approach combined terms for 'feedback' and terms which described either the effectiveness of feedback or terms which are used in qualitative study designs such as 'qualitative', 'experience' and 'interview' (16). The qualitative study design terminology recognised that many of the papers from our pilot searches that were providing the most detailed information in relation to the Research Questions were qualitative. However, we did not wish to exclude other study designs, hence these terms were combined using OR with terms which described the effectiveness of feedback which are not 
This is the peer reviewed version of the following article: Mattick, K. , Brennan, N. , Briscoe, S. , Papoutsi, C. and Pearson, M. (2019), Optimising feedback for early career professionals: a scoping review and new framework. Med Educ, 53: 355-368, which has been published in final form at https://doi.org/10.1111/medu.13794. This article may be used for non-commercial purposes in accordance with Wiley Terms and Conditions for Use of Self-Archived Versions.

specifically related to a particular study type. Given the study's resource constraints, we used a date limit of 1990 onwards, selected since it encompassed many key professional education developments, and an English language filter.

\section{Search strategy}

The databases searched (Box 1) were selected to provide coverage of medicine, health care more broadly, education, and other professions. The Ovid MEDLINE search strategy is presented in Figure 1. The search results were supplemented by checking the reference lists of the studies included in the synthesis stage of the review.

\section{Mapping stage}

The aim of the mapping stage was to describe the inevitably broad and diverse literature, in order to make an informed decision about which studies would contribute substantially to the framework development stage (17). The inclusion criteria for both stages are described in Table 1 . For the mapping stage, the first $10 \%$ of the titles and abstracts were assessed independently and then compared by two review authors (KM and MP). Any differences in opinion were resolved through discussion, with a third author resolving disagreements. The remaining title and abstracts (90\%) were assessed by KM. Any uncertainties were discussed by KM and MP and, where necessary, all authors. The reasons for excluding papers are given in Figure 2. Endnote was used to manage the screening stage.

The 92 studies included at this stage were read in full by one of three authors (NB, CP, KM) to assess whether the article still met the inclusion criteria having read the full text, with all papers recommended for exclusion referred to another author (MP), and all authors reviewing these decisions to ensure consistency of approach. Data extraction categories were informed by the template for intervention description and replication (TIDieR) checklist and guide (21) because this articulated the kinds of information required to describe feedback interventions. 
This is the peer reviewed version of the following article: Mattick, K. , Brennan, N. , Briscoe, S. , Papoutsi, C. and Pearson, M. (2019), Optimising feedback for early career professionals: a scoping review and new framework. Med Educ, 53: 355-368, which has been published in final form at https://doi.org/10.1111/medu.13794. This article may be used for non-commercial purposes in accordance with Wiley Terms and Conditions for Use of Self-Archived Versions.

Data were extracted by one author and verified by a second, using a standardised form in

Microsoft Word. Since the aim of the mapping stage was to characterise existing literature on a particular topic in order to make an informed decision about whether to undertake in-depth review and synthesis, we did not undertake quality assessment at this stage.

\section{Framework development stage}

A subset of the included papers were selected based on specific inclusion criteria (see Table 1) to be subjected to a second phase of data analysis called framework development. All selection decisions were made by three authors $(\mathrm{KM}, \mathrm{CP}, \mathrm{NB})$ and papers were not excluded based on study design. Our approach to drawing the literature together to create a framework was 'configuring' rather than 'aggregating' (17). So rather than focussing on 'multiple observations of the same phenomena' (p87), the aim of this stage was to place 'study findings alongside one another in order to build up a picture of the whole, and how they relate to one another' (p88), which is more achievable for diverse literatures. To 'configure' our studies, we drew on the principles of thematic synthesis.

\section{Thematic synthesis}

We read each study line-by line, made notes, charted key observations and revisited the text to extract the key ideas, concepts and messages. In doing so, we focussed as much on author explanations for the observed findings as the findings themselves. We went through each paper highlighting the sections that contribute to the research questions and making comments/codes about how they do that, which we then discussed and combined, ultimately leading to a Feedback Framework. The process was not entirely inductive as it was driven by the research questions and Feedback Intervention Theory, and involved a wide range of study designs. 
This is the peer reviewed version of the following article: Mattick, K. , Brennan, N. , Briscoe, S. , Papoutsi, C. and Pearson, M. (2019), Optimising feedback for early career professionals: a scoping review and new framework. Med Educ, 53: 355-368, which has been published in final form at https://doi.org/10.1111/medu.13794. This article may be used for non-commercial purposes in accordance with Wiley Terms and Conditions for Use of Self-Archived Versions.

\section{Quality assessment}

Scoping reviews are not required to undertake quality appraisal (14). Thus, while we did not exclude any papers on the basis of quality (since there is little empirical basis on which to do this), we did interpret and make sense of the different aspects that these papers presented throughout the analysis process, taking into account the paradigm they belonged to, how well each of their arguments were made on the basis of data and how the different papers corroborated each other. This was carried out predominantly by one author (KM), with input from three further authors (NB, CP, MP). We have made this process transparent in Table 5 , which contains a column for 'strength of evidence'.

\section{Results}

\section{$\underline{\text { Papers identified }}$}

The total number of hits retrieved from each database search is detailed in Table 2 and a flow diagram showing which papers were included is given in Figure 2. Through searching the reference lists of the included studies, 57 additional references were identified as potentially interesting, of which 24 had already been identified by our database search. Of the remaining 33, 21 did not meet our inclusion criteria, 4 were duplicates and 1 (an earlier version of a Cochrane review) had been withdrawn, leaving 7 papers ( 2 empirical, 5 literature reviews) that were read in full and included in the mapping stage. A subset of 17 of the papers from the mapping stage were included in the framework development stage.

\section{Mapping the literature}

In total, 80 studies were included in the mapping stage. Of these, 60 were empirical studies (more details about the studies are presented in Table 3). Six were published between 1990 and 1999; 20 were published 2000-2009; and 34 were published in 2010 or beyond. The USA 
This is the peer reviewed version of the following article: Mattick, K. , Brennan, N. , Briscoe, S. , Papoutsi, C. and Pearson, M. (2019), Optimising feedback for early career professionals: a scoping review and new framework. Med Educ, 53: 355-368, which has been published in final form at https://doi.org/10.1111/medu.13794. This article may be used for non-commercial purposes in accordance with Wiley Terms and Conditions for Use of Self-Archived Versions.

published the vast majority of the included empirical studies (41 papers). In terms of study design, 49/60 were quantitative non-randomised, 6 were quantitative randomised, 4 were mixed methods and one was qualitative. The numbers of participants receiving feedback in these studies was often unclear but varied from 1 to 180 participants. In terms of settings, 36 involved hospitals and 24 involved schools. In general, the participant numbers were greater in hospital settings, with smaller numbers in the studies involving schools. Only 18 / 60 empirical studies focussed specifically on early career professionals. There were also 20 literature reviews included in the mapping stage (Table 4). Of these, 3 were published 19901999, 8 were published 2000-2009 and 9 were published in 2010 or more recently. Most were from studies in healthcare settings (17), with only 2 from schools and 1 was a theoretical paper that was not context-specific. The number of included studies varied from 7 to 140 . The literature reviews generally focussed on quantifying the effectiveness of feedback rather than optimising the process.

\section{Developing the Feedback Framework}

We reviewed 17 papers in the framework development stage (11 empirical studies - 6 quantitative, 4 mixed, 1 qualitative - and 6 literature reviews). This subset was narrower in scope, with over half the papers focussing specifically on ECPs $(9 / 17)$, most coming from a healthcare context (14/17) and all providing in-depth analysis of contextual features. The included papers did not contain an existing feedback taxonomy or framework that was broad enough to accommodate the literature found. We therefore created one through this research (Table 5) and used it to organise the findings. The Feedback Framework incorporated the findings of the included papers to conceptualise workplace-based feedback interventions as comprising 3 main categories (Audit, Feedback, and Goal-Setting), with 22 subcategories. The categories and sub-categories are summarised in Table 5, with an indication of the 
This is the peer reviewed version of the following article: Mattick, K. , Brennan, N. , Briscoe, S. , Papoutsi, C. and Pearson, M. (2019), Optimising feedback for early career professionals: a scoping review and new framework. Med Educ, 53: 355-368, which has been published in final form at https://doi.org/10.1111/medu.13794. This article may be used for non-commercial purposes in accordance with Wiley Terms and Conditions for Use of Self-Archived Versions.

strength of the evidence underpinning each subcategory, so that researchers can target their future work on aspects that have less robust evidence.

Overall, there appeared to be a lack of clarity and consistency in the use of terminology in the included studies, combined with a lack of specificity in discussing the different components of 'feedback'. The Effective Practice and Organisation of Care (EPOC) group who undertook the most recent Cochrane review of audit and feedback (3) say "In an audit and feedback process, an individual's professional practice or performance is measured and then compared to professional standards or targets. In other words, their professional performance is "audited". The results of this comparison are then fed back to the individual. The aim of this process is to encourage the individual to follow professional standards". However we feel this definition seems to conflate the process of feeding back the data collected through the audit and the process of reflecting on the data and setting goals and an action plan to bring about a change in performance, even though this latter aspect was deemed important in its own right within the papers we reviewed. We also recognise that the observed performance is underpinned by complex clinical reasoning. In addition, the definition promotes the following of professional standards, whereas a critical role for a professional might be to decide when it is not appropriate to follow the guidance. Similarly, Kluger and DeNisi (5) consider inter-personal issues to be separate to feedback whereas other research suggests interprofessional issues are core. To improve transparency of feedback interventions, Ivers et al. (4) called for better reporting but, although the number of papers was limited, we did not see a marked improvement in reporting in the most recently published papers.

Table 5 outlines the three main categories of the Feedback Framework we have developed (Audit, Feedback, Goal-setting), each with sub-categories. It presents a synthesis of knowledge 
This is the peer reviewed version of the following article: Mattick, K. , Brennan, N. , Briscoe, S. , Papoutsi, C. and Pearson, M. (2019), Optimising feedback for early career professionals: a scoping review and new framework. Med Educ, 53: 355-368, which has been published in final form at https://doi.org/10.1111/medu.13794. This article may be used for non-commercial purposes in accordance with Wiley Terms and Conditions for Use of Self-Archived Versions.

from the included papers and indicates the strength of the evidence. Here we provide a brief overview of the three categories.

Audit in this context relates to the collection of data regarding some aspect of one's task performance. The Oxford Dictionaries defines audit as "A systematic review or assessment of something" (https://en.oxforddictionaries.com/definition/audit). Other authors have referred to 'performance measurement' instead (Redwood et al. 2013) or have only referred to audit implicitly (5). In the audit category, the 6 subcategories developed from analysis of our data were: complexity of task chosen; type of task chosen; nature of data to be collected; metric importance to the intended recipient; data credibility; and baseline performance (Table 5). According to the literature reviewed, less complex tasks or behaviours are probably easier to change through feedback. Where feedback metrics were aligned to the priorities of the recipient and/or organisation, they seemed likely to have greater impact, although feedback messages could be undermined by contextual cues or other feedback sources. Feedback seemed most effective when baseline performance was low, which is likely for ECPs, but if it was very low then rapid improvement might be needed to sustain engagement with the task. Importantly, for ECPs who often work under supervision, or where teamwork or shift work is common, performance data were sometimes deemed an unfair reflection of ECP's own clinical practice, which could undermine the feedback process (e.g. 'Junior doctors explained that because they rarely made prescribing decisions independently, the feedback letters should be sent to all team members, including the senior doctors.') (30 p. 587).

In the methods section, we defined feedback as 'actions taken by (an) external agent(s) to provide information regarding some aspect(s) of one's task performance' (5); in other words, the way in which audit data are made available to the feedback recipient. Information may be provided via a range of means and can be presented in a range of ways, for example with or 
This is the peer reviewed version of the following article: Mattick, K. , Brennan, N. , Briscoe, S. , Papoutsi, C. and Pearson, M. (2019), Optimising feedback for early career professionals: a scoping review and new framework. Med Educ, 53: 355-368, which has been published in final form at https://doi.org/10.1111/medu.13794. This article may be used for non-commercial purposes in accordance with Wiley Terms and Conditions for Use of Self-Archived Versions.

without comparisons to other data. In the category of feedback intervention, the 7

subcategories were: feedback format; comparison to other data; judgment made on data; content of feedback; likelihood of feedback to be perceived as a threat; correct solution information; and timing and frequency of feedback (Table 5). Written feedback seemed more effective than verbal or graphical delivery. Comparison to past performance (e.g. feedback on progress over time) tended to be effective, since it directed attention to the task, whereas public feedback, peer comparisons, praise and discouragement could divert attention to metatask aspects involving the self (e.g. emotional responses, concerns about implications). Clay et al. propose debriefing cards as 'a tool for deliberate practice' improving trainee performance by providing 'the opportunity for frequent self-assessment, explicit expectations for performance, and feedback on each resident's self-assessment by a supervising physician' (11 p743). Feedback could sometimes be perceived as a threat to self-esteem or to external rewards/punishments, so the benefits of 'authoritative' sources must be weighed up against the risks of this making the feedback seem more threatening. Providing a 'correct solution' as part of feedback was thought to increase its likely impact by focussing attention on target behaviour but correct solutions may be scarce within professional practice, where complex judgments in a messy practice context are common. Feedback was thought to be most effective when presented more than once and when it occurred soon after the performance event.

Goal-setting, the final category in our Feedback Framework, occurs when the feedback recipient considers behavioural change based on the information received. Providing information, alone, is often insufficient to change behaviour or outcomes. In this category, the 9 subcategories were: presence or absence of goal-setting; presence of a reviewer to support goal-setting; relationship to reviewer; nature of goal; tailoring of goal setting conversation; nature of conversation; recipient ownership of goal setting; acceptance of goals suggested; 
This is the peer reviewed version of the following article: Mattick, K. , Brennan, N. , Briscoe, S. , Papoutsi, C. and Pearson, M. (2019), Optimising feedback for early career professionals: a scoping review and new framework. Med Educ, 53: 355-368, which has been published in final form at https://doi.org/10.1111/medu.13794. This article may be used for non-commercial purposes in accordance with Wiley Terms and Conditions for Use of Self-Archived Versions.

and successful completion of goals (Table 5). Knowing what to do with feedback seemed as important as receiving it. The included studies suggested that feedback was more effective when combined with reflection and/or goals and an action plan. Most included studies involved a reviewer in goal-setting, who needed to be perceived as credible. A quality goalsetting conversation could help learners to identify the gap between current and desired performance and agree a strategy for change. Goals seemed unlikely to be accepted or prioritised if the immediate relevance to practice setting was unclear. As Redwood et al. note ' '...metrics used need to be concrete rather than abstract and must reflect actual work processes which may be different in different clinical contexts (e.g. working on a day or night shift, or in a surgical or medical speciality).' (27 p. 9). Goals also needed to be within the scope of responsibility or possibility of the ECP. It seemed important for recipients to discuss the performance context, since sometimes apparent 'poor performance' could be explained when placed in context.

\section{Modified Feedback Intervention Theory for ECPs}

A key question underpinning our research was the extent to which ECPs were a specific group, with different needs and contextual influences than other professional groups. Therefore Table 6 outlines some key features of Feedback Intervention Theory (5), which in its original form was offered as a universal model, and highlights where our research indicates that it might need to be extended or given extra weighting to accommodate the particular situation of feedback for ECPs in busy work environments.

\section{Discussion}

The aim of this scoping review was to bring together information which can support the optimal design of workplace-based feedback interventions for early career professionals. We mapped the literature that exists already and organised the most relevant literature into a 
This is the peer reviewed version of the following article: Mattick, K. , Brennan, N. , Briscoe, S. , Papoutsi, C. and Pearson, M. (2019), Optimising feedback for early career professionals: a scoping review and new framework. Med Educ, 53: 355-368, which has been published in final form at https://doi.org/10.1111/medu.13794. This article may be used for non-commercial purposes in accordance with Wiley Terms and Conditions for Use of Self-Archived Versions.

Feedback Framework (Table 5), developed for this study, which we now offer as a tool to optimise the design of future feedback interventions. The detailed analysis allowed us to answer the research questions by identifying the specific features of feedback interventions for ECPs that seemed to underpin their effectiveness (or ineffectiveness) and by trying to explain why these features were important and how they might work (Table 5). We addressed the final research question by exploring the extent to which Feedback Intervention Theory in its existing format could accommodate ECPs, which led us to identify some specific nuances associated with ECPs that we felt needed modification, or greater emphasis, in a "FIT for ECPs" (Table 6).

It is clear that feedback interventions have the potential for significant positive impact and that ECPs are an appropriate target group who may stand to gain the most benefit from feedback. However, our review suggests that few studies provided a convincing rationale that their feedback intervention design was optimal, and very few focussed on ECPs alone, so we believe it is likely that the impact of current and future interventions can be significantly improved. Our analysis of findings against the existing Feedback Intervention Theory suggests that it would need to be modified in order to take account of the key features influencing feedback for ECPs. Colquhoun et al. (8) suggested that a taxonomy of feedback interventions would improve the design, description and reporting of feedback interventions and we hope our Feedback Framework might contribute towards this aim.

Like previous researchers $(3,5,18-20)$, we note a need for more detailed reporting of feedback interventions, with rich descriptions of the different components and rationale for their combination, in order to share experiences, build theory or synthesise evidence across studies. Although these are challenges in many domains, it is particularly important for complex, multistage interventions such as feedback. In healthcare the terminology 'audit and 
This is the peer reviewed version of the following article: Mattick, K. , Brennan, N. , Briscoe, S. , Papoutsi, C. and Pearson, M. (2019), Optimising feedback for early career professionals: a scoping review and new framework. Med Educ, 53: 355-368, which has been published in final form at https://doi.org/10.1111/medu.13794. This article may be used for non-commercial purposes in accordance with Wiley Terms and Conditions for Use of Self-Archived Versions.

feedback' seems to have become established in the literature but seems to underplay the important steps that occur after feedback is received and before behaviour change occurs, which are highlighted through our included papers and other literature (22-24). The literature reviews included in our scoping review typically only synthesised quantitative studies (19) and often only RCTs $(3,4,18,25)$. A broader range of empirical research methodologies would provide greater insights into mechanisms and unintended consequences, and different types of literature review such as qualitative metasyntheses, realist reviews, or other theory-based approaches to evidence syntheses (26). A stronger theoretical basis is also needed.

Colquhoun et al. (8) developed a list of testable theory-informed hypotheses about feedback, which sets out a useful research agenda and makes a first step in linking theory to practice, but evidence syntheses and frameworks are now required to inform the design of feedback interventions for specific recipient groups, since the primary data is challenging and timeconsuming to interpret (18).

\section{$\underline{\text { Recommendations for policy and practice }}$}

Based on the literature included in this study we recommend that: feedback interventions focus on an important aspect of performance; the data selected are credible and reflective of individual performance of the target audience, in our case ECPs; information should be communicated privately and mapped against appropriate external standards (relevant to stage of training) with clear information about the standard sought; supportive, developmental opportunities to discuss feedback and set goals are provided with an experienced professional who is familiar with the specific practice context and has good facilitation skills; and that the goals are within the ECP's scope of practice. However it is hard to predict effectiveness of feedback interventions (27-30), since subtle changes of context or process can make a big difference (31) and subtle nuances can affect how the feedback message is received (31). 
This is the peer reviewed version of the following article: Mattick, K. , Brennan, N. , Briscoe, S. , Papoutsi, C. and Pearson, M. (2019), Optimising feedback for early career professionals: a scoping review and new framework. Med Educ, 53: 355-368, which has been published in final form at https://doi.org/10.1111/medu.13794. This article may be used for non-commercial purposes in accordance with Wiley Terms and Conditions for Use of Self-Archived Versions.

The Feedback Framework developed through this research is offered to support the design (or re-design) of feedback interventions for ECPs. Through Table 5, we have highlighted the strength of the evidence base underpinning each stage of the Feedback Framework, using a format applied successfully for communicating with policy makers and education professionals (2). Table 5 also signposts the original publications underpinning each summary judgment, so that feedback intervention designers can engage with the evidence first-hand should they wish to. We hope that providing easy access to the theory and evidence underpinning each stage of the Feedback Framework will enable future interventions to be more likely to have a greater impact.

\section{$\underline{\text { Recommendations for future research }}$}

The Feedback Framework also serves to highlight those aspects of feedback which have received a lot of attention by researchers and those which have been neglected to date. By mapping which aspects of the framework are well populated with research, we hope to be able to ensure that research efforts are channelled to those areas most neglected currently and do not waste resources duplicating what is already well established in the literature (4). Topics requiring future attention include the impact of the types and complexities of tasks chosen for a feedback intervention, perceptions of feedback recipients about the nature of the data chosen for feedback, the impact of praise or displeasure on the feedback recipient, and the process and implications of the goal-setting conversation (Table 5). For example it would be interesting to understand how highly experienced mentors, or those who know the individual feedback recipient, implicitly tailor their feedback. But most importantly, we encourage future feedback research to move away from generic models and tailor their work to the specific target groups targeted by feedback interventions. 
This is the peer reviewed version of the following article: Mattick, K. , Brennan, N. , Briscoe, S. , Papoutsi, C. and Pearson, M. (2019), Optimising feedback for early career professionals: a scoping review and new framework. Med Educ, 53: 355-368, which has been published in final form at https://doi.org/10.1111/medu.13794. This article may be used for non-commercial purposes in accordance with Wiley Terms and Conditions for Use of Self-Archived Versions.

Like Hysong 2009 (18), we felt Feedback Intervention Theory provided a useful theoretical framework to guide decisions in designing future feedback interventions. Despite offering a very interesting perspective on feedback, it was cited by very few of the studies included in our scoping review. We recommend that Feedback Intervention Theory or modifications thereof, as well as other behavioural and social sciences theories, are given greater attention in future research.

Interestingly, in some of the studies included in the synthesis stage, the feedback intervention did not work as anticipated $(27,29)$. As with all complex interventions, we need to be alert to unintended consequences and see these as important opportunities for learning. Studies involving observation may provide new insights to workplace contexts in which unanticipated events have occurred. Other future studies might interview multiple stakeholders in feedback interventions that have worked particularly well or particularly badly, to try and identify common themes. The future is also likely to involve easier access to electronic performance data, which will provide new opportunities to evaluate feedback interventions (32), although concerns have been raised about the panoptic gaze on clinical practice (27).

\section{Strengths and limitations of the research}

The strengths of this work are the rigorous two-stage scoping review process undertaken by a multidisciplinary team; the deliberately broad methodology to incorporate relevant literature beyond the healthcare setting; the focus on busy workplaces and naturally occurring measures; and the inclusion of a wide range of study designs. Our team included an information scientist, implementation scientist and social scientist as well as medical educators. Our review allowed a comparison of literature across two key 'hot action' environments: hospital wards and school classrooms, since similar numbers of empirical 
This is the peer reviewed version of the following article: Mattick, K. , Brennan, N. , Briscoe, S. , Papoutsi, C. and Pearson, M. (2019), Optimising feedback for early career professionals: a scoping review and new framework. Med Educ, 53: 355-368, which has been published in final form at https://doi.org/10.1111/medu.13794. This article may be used for non-commercial purposes in accordance with Wiley Terms and Conditions for Use of Self-Archived Versions.

studies were included in the mapping stage. In general, the number of participants was smaller for school settings in the included papers and there were fewer literature reviews.

As with all research studies, there are also some limitations. The summary of evidence derived from a scoping review can only be as good as the literature it finds. Resource constraints meant we only looked at literature since 1990 and published in English language. The fact that feedback intervention reports were mostly positive raises concerns about both publication bias (in that unsuccessful or negative impact feedback interventions may not be published (19)) and selection bias (in that the research participants who engage with feedback may reflect those more motivated trainees (33)). We believe studies that don't work as intended or participants who aren't keen to participate are well placed to contribute important new insights. Also, given the limitations of reporting and methodologies described, we are unlikely to know whether feedback interventions took place as intended (29) and not all the included literature focussed solely on ECPs. More mixed methods research, for example incorporating a qualitative process evaluation, would help with this. As McLellan et al. put it, 'the social world is a complex one and we would not therefore be able to explain how or why our intervention had an effect on the basis of numeric data alone' (28). Finally, our search does not claim to be exhaustive and the Feedback Framework developed is just one interpretation, but we hope it can start an interesting and important conversation about workplace-based feedback in ECPs.

\section{$\underline{\text { Conclusions }}$}

The aim of this scoping review was to bring together information which can support the optimal design of workplace-based feedback interventions for ECPs. The Feedback Framework we developed comprised 3 main categories (Audit, Feedback, and Goal-Setting) and 22 subcategories. The evidence summary highlighted imprecise terminology; patchy research 
This is the peer reviewed version of the following article: Mattick, K. , Brennan, N. , Briscoe, S. , Papoutsi, C. and Pearson, M. (2019), Optimising feedback for early career professionals: a scoping review and new framework. Med Educ, 53: 355-368, which has been published in final form at https://doi.org/10.1111/medu.13794. This article may be used for non-commercial purposes in accordance with Wiley Terms and Conditions for Use of Self-Archived Versions.

coverage across the Feedback Framework; and limited research focussing on ECPs. Comparing our findings with the existing Feedback Intervention Theory allowed the specific nuances associated with feedback for ECPs to be made explicit. We now offer the Feedback Framework and our tailoring of FIT for ECPs to help optimise the design of future feedback interventions; and to help researchers identify priorities for study.

\section{References}

1. Hattie J, Timperley H. The power of feedback. Review of Educational Research. 2007;77(1):81-112.

2. Education Endowment Foundation. Teaching and Learning Toolkit [Available from: https://educationendowmentfoundation.org.uk/evidence-summaries/teaching-learningtoolkit].

3. Ivers N, Jamtvedt G, Flottorp S, Young JM, Odgaard-Jensen J, French SD, et al. Audit and feedback: effects on professional practice and healthcare outcomes. Cochrane Database of Systematic Reviews. 2012(6).

4. Ivers NM, Grimshaw JM, Jamtvedt G, Flottorp S, O'Brien MA, French SD, et al. Growing literature, stagnant science? Systematic review, meta-regression and cumulative analysis of audit and feedback interventions in health care. Journal of General Internal Medicine. 2014;29(11):1534-41.

5. Kluger AN, DeNisi A. The effects of feedback interventions on performance: a historical review, a meta-analysis, and a preliminary feedback intervention theory. Psychological Bulletin. 1996;119(2):254-84.

6. Fraser SW, Greenhalgh T. Coping with complexity: educating for capability. BMJ. 2001;323:799. 
This is the peer reviewed version of the following article: Mattick, K. , Brennan, N. , Briscoe, S. , Papoutsi, C. and Pearson, M. (2019), Optimising feedback for early career professionals: a scoping review and new framework. Med Educ, 53: 355-368, which has been published in final form at https://doi.org/10.1111/medu.13794. This article may be used for non-commercial purposes in accordance with Wiley Terms and Conditions for Use of Self-Archived Versions.

7. Colquhoun HL, Brehaut JC, Sales A, Ivers N, Grimshaw J, Michie S, et al. A systematic review of the use of theory in randomized controlled trials of audit and feedback. Implementation Science. 2013;8:66.

8. Colquhoun HL, Carroll K, Eva KW, Grimshaw JM, Ivers N, Michie S, et al. Advancing the literature on designing audit and feedback interventions: identifying theory-informed hypotheses. Implementation Science. 2017;12(1):117.

9. Ramani S, Krackov SK. Twelve tips for giving feedback effectively in the clinical environment. Medical Teacher. 2012;34(10):787-91.

10. Papoutsi C, Mattick K, Pearson M, Brennan N, Briscoe S, Wong G. Social and professional influences on antimicrobial prescribing for doctors-in-training: a realist review. Journal of Antimicrobial Chemotherapy. 2017;72(9):2418-30.

11. Eraut M. Feedback. Learning in Health and Social Care. 2006;5(3):111-8.

12. Eraut M. Informal learning in the workplace. Studies in Continuing Education. 2004;26(2):247-73.

13. van de Ridder JMM, McGaghie WC, Stokking KM, ten Cate OTJ. Variables that affect the process and outcome of feedback, relevant for medical training: a meta-review. Medical Education. 2015;49(7):658-73.

14. Grant MJ, Booth A. A typology of reviews: an analysis of 14 review types and associated methodologies. Health Information \& Libraries Journal. 2009;26(2):91-108. 15. Arksey H, O'Malley L. Scoping studies: towards a methodological framework. International Journal of Social Research Methodology. 2005;8(1):19-32.

16. Wong SSL, Wilczynski, N. L., Haynes, R. B. Developing optimal search strategies for detecting clinically relevant qualitative studies in MEDLINE. Stud Health Technol Inform. 2004;107(1):311-6.

17. Gough D, Thomas J. Systematic reviews of research in education: aims, myths and multiple methods. Review of Education. 2016;4(1):84-102. 
This is the peer reviewed version of the following article: Mattick, K. , Brennan, N. , Briscoe, S. , Papoutsi, C. and Pearson, M. (2019), Optimising feedback for early career professionals: a scoping review and new framework. Med Educ, 53: 355-368, which has been published in final form at https://doi.org/10.1111/medu.13794. This article may be used for non-commercial purposes in accordance with Wiley Terms and Conditions for Use of Self-Archived Versions.

18. Hysong SJ. Meta-analysis: audit and feedback features impact effectiveness on care quality. Medical Care. 2009;47(3):356-63.

19. Rogers RLG, Narvaez Y, Venkatesh AK, Fleischman W, Hall MK, Taylor RA, et al. Improving emergency physician performance using audit and feedback: a systematic review. American Journal of Emergency Medicine. 2015;33(10):1505-14.

20. Larson EL, Patel SJ, Evans D, Saiman L. Feedback as a strategy to change behaviour: the devil is in the details. Journal of Evaluation in Clinical Practice. 2013;19(2):230-4.

21. Hoffmann TC, Glasziou PP, Boutron I, Milne R, Perera R, Moher D, et al. Better reporting of interventions: template for intervention description and replication (TIDieR) checklist and guide. BMJ : British Medical Journal. 2014;348.

22. Sargeant JM, Mann KV, van der Vleuten CP, Metsemakers JF. Reflection: a link between receiving and using assessment feedback. Advances in Health Sciences Education. 2009;14(3):399-410.

23. Gude WT, Roos-Blom M-J, van der Veer SN, Dongelmans DA, de Jonge E, Francis JJ, et al. Health professionals' perceptions about their clinical performance and the influence of audit and feedback on their intentions to improve practice: a theory-based study in Dutch intensive care units. Implementation Science. 2018;13(1):33.

24. Brennan N, Bryce M, Pearson M, Wong G, Cooper C, Archer J. Towards an understanding of how appraisal of doctors produces its effects: a realist review. Medical Education. 2017;51(10):1002-13.

25. Jamtvedt G, Young JM, Kristoffersen DT, O'Brien MA, Oxman AD. Does telling people what they have been doing change what they do? A systematic review of the effects of audit and feedback. Quality and Safety in Health Care. 2006;15(6):433-6.

26. Gardner B, Whittington C, McAteer J, Eccles MP, Michie S. Using theory to synthesise evidence from behaviour change interventions: the example of audit and feedback. Social Science \& Medicine. 2010;70(10):1618-25. 
This is the peer reviewed version of the following article: Mattick, K. , Brennan, N. , Briscoe, S. , Papoutsi, C. and Pearson, M. (2019), Optimising feedback for early career professionals: a scoping review and new framework. Med Educ, 53: 355-368, which has been published in final form at https://doi.org/10.1111/medu.13794. This article may be used for non-commercial purposes in accordance with Wiley Terms and Conditions for Use of Self-Archived Versions.

27. Redwood S, Ngwenya NB, Hodson J, Ferner RE, Coleman JJ. Effects of a computerized feedback intervention on safety performance by junior doctors: results from a randomized mixed method study. BMC Medical Informatics \& Decision Making. 2013;13(1):63.

28. McLellan L, Dornan T, Newton P, Williams SD, Lewis P, Steinke D, et al. Pharmacist-led feedback workshops increase appropriate prescribing of antimicrobials. Journal of Antimicrobial Chemotherapy (JAC). 2016;71(5):1415-25.

29. Milanowski AT. Split Roles in Performance Evaluation-A Field Study Involving New Teachers. Journal of Personnel Evaluation in Education. 2005;18(3):153-69.

30. Baysari MT, Oliver K, Egan B, Li L, Richardson K, Sandaradura I, et al. Audit and feedback of antibiotic use: utilising electronic prescription data. Applied Clinical Informatics. 2013;4(4):583-95.

31. Boekeloo BO, Becker DM, Levine DM, Belitsos PC, Pearson TA. Strategies for increasing house staff management of cholesterol with inpatients. American Journal of Preventive Medicine. 1990;6(2 Suppl):51-9.

32. Brinkman WB, Geraghty SR, Lanphear BP, Khoury JC, Gonzalez del Rey JA, DeWitt TG, et al. Effect of multisource feedback on resident communication skills and professionalism: a randomized controlled trial. Archives of Pediatrics \& Adolescent Medicine. 2007;161(1):44-9. 33. Clay AS, Que L, Petrusa ER, Sebastian M, Govert J. Debriefing in the intensive care unit: a feedback tool to facilitate bedside teaching. Critical Care Medicine. 2007;35(3):738-54. 34. Hadjianastassiou VG KD, Gavalas M. A comparison between different formats of educational feedback to junior doctors: a prospective pilot intervention study. J R Coll Surg Edinb. 2001;46(6):354-7.

35. Holmboe E, Scranton R, Sumption K, Hawkins R. Effect of medical record audit and feedback on residents' compliance with preventive health care guidelines. Academic Medicine. 1998;73(8):901-3. 
This is the peer reviewed version of the following article: Mattick, K. , Brennan, N. , Briscoe, S. , Papoutsi, C. and Pearson, M. (2019), Optimising feedback for early career professionals: a scoping review and new framework. Med Educ, 53: 355-368, which has been published in final form at https://doi.org/10.1111/medu.13794. This article may be used for non-commercial purposes in accordance with Wiley Terms and Conditions for Use of Self-Archived Versions.

36. Jamtvedt G YJ, Kristoffersen DT, Thomson O'Brien MA, Oxman AD. Audit and feedback: effects on professional practice and health care outcomes. The Cochrane Database of Systematic Reviews 2003(3).

37. Lavoie CF, Schachter H, Stewart AT, McGowan J. Does outcome feedback make you a better emergency physician? A systematic review and research framework proposal. CJEM. 2009;11(6):545-52.

38. Mugford M BP, O'Hanlon M. Effects of feedback of information on clinical practice: a review. BMJ. 1991;303:398-402.

39. Shojania KG JA, Mayhew A, Ramsay C, Eccles M, Grimshaw J. Effect of point-of-care computer reminders on physician behaviour: a systematic review. CMAJ 2010;182(5):E216E25.

40. Abu-Hanna A, Eslami S, Schultz MJ, de Jonge E, de Keizer NF. Analyzing effects of providing performance feedback at ward rounds on guideline adherence - the importance of feedback usage analysis and statistical control charts. Studies in Health Technology \& Informatics. 2010;160(Pt 2):826-30.

41. Alagha $\mathrm{HZ}$, Badary OA, Ibrahim HM, Sabri NA. Reducing prescribing errors in the paediatric intensive care unit: an experience from Egypt. Acta Paediatrica. 2011;100(10):e16974.

42. Briere DE. Increasing New Teachers' Specific Praise Using a Within-School Consultation Intervention: ProQuest LLC; 2012.

43. Briere DE, Simonsen B, Sugai G, Myers D. Increasing New Teachers' Specific Praise Using a within-School Consultation Intervention. Journal of Positive Behavior Interventions. 2015;17(1):50-60.

44. Brock VB. The impact of performance feedback on handwashing behaviors: University of Alabama at Birmingham; 2002. 
This is the peer reviewed version of the following article: Mattick, K. , Brennan, N. , Briscoe, S. , Papoutsi, C. and Pearson, M. (2019), Optimising feedback for early career professionals: a scoping review and new framework. Med Educ, 53: 355-368, which has been published in final form at https://doi.org/10.1111/medu.13794. This article may be used for non-commercial purposes in accordance with Wiley Terms and Conditions for Use of Self-Archived Versions.

45. Chern C, How C, Wang L, Lee C, Graff L. Decreasing clinically significant adverse events using feedback to emergency physicians of telephone follow-up outcomes. Annals of Emergency Medicine. 2005;45(1):15-23.

46. Codding RS, Feinberg AB, Dunn EK, Pace GM. Effects of immediate performance feedback on implementation of behavior support plans. Journal of Applied Behavior Analysis. 2005;38(2):205-19.

47. Colvin G, Flannery KB, Sugai G, Monegan J. Using Observational Data to Provide Performance Feedback to Teachers: A High School Case Study. Preventing School Failure. 2009;53(2):95-104.

48. Cuticelli M, Collier-Meek M, Coyne M. Increasing the Quality of Tier 1 Reading Instruction: Using Performance Feedback to Increase Opportunities to Respond during Implementation of a Core Reading Program. Psychology in the Schools. 2016;53(1):89-105. 49. DiGennaro FD, Martens BK, Kleinmann AE. A comparison of performance feedback procedures on teachers' treatment implementation integrity and students' inappropriate behavior in special education classrooms. Journal of Applied Behavior Analysis. 2007;40(3):447-61.

50. Digennaro-Reed FD, Codding R, Catania CN, Maguire H. Effects of video modeling on treatment integrity of behavioral interventions. Journal of Applied Behavior Analysis. $2010 ; 43(2): 291-5$.

51. Duncan NG, Dufrene BA, Sterling HE, Tingstrom DH. Promoting Teachers'

Generalization of Intervention Use Through Goal Setting and Performance Feedback. Journal of Behavioral Education. 2013;22(4):325-47.

52. Eveillard M, Raymond F, Guilloteau V, Pradelle MT, Kempf M, Zilli-Dewaele M, et al. Impact of a multi-faceted training intervention on the improvement of hand hygiene and gloving practices in four healthcare settings including nursing homes, acute-care geriatric wards and physical rehabilitation units. Journal of Clinical Nursing. 2011;20(19-20):2744-51. 
This is the peer reviewed version of the following article: Mattick, K. , Brennan, N. , Briscoe, S. , Papoutsi, C. and Pearson, M. (2019), Optimising feedback for early career professionals: a scoping review and new framework. Med Educ, 53: 355-368, which has been published in final form at https://doi.org/10.1111/medu.13794. This article may be used for non-commercial purposes in accordance with Wiley Terms and Conditions for Use of Self-Archived Versions.

53. Fakih MG, Jones K, Rey JE, Berriel-Cass D, Kalinicheva T, Szpunar S, et al. Sustained improvements in peripheral venous catheter care in non-intensive care units: a quasiexperimental controlled study of education and feedback. Infection Control \& Hospital Epidemiology. 2012;33(5):449-55.

54. Feely J, Chan R, Cocoman L, Mulpeter K, O'Connor P. Hospital formularies: need for continuous intervention. BMJ. 1990;300(6716):28-30.

55. Frenzel JC, Kee SS, Ensor JE, Riedel BJ, Ruiz JR. Ongoing provision of individual clinician performance data improves practice behavior. Anesthesia \& Analgesia. 2010;111(2):515-9. 56. Fuller C, Michie S, Savage J, McAteer J, Besser S, Charlett A, et al. The Feedback Intervention Trial (FIT)--improving hand-hygiene compliance in UK healthcare workers: a stepped wedge cluster randomised controlled trial. PLoS ONE [Electronic Resource]. 2012;7(10):e41617.

57. Fung Kee Fung MP, Parboosingh IJ, Temple LM, Guy d'Anjou C, Haebe J, Lussier R. Development of a computerized telecommunication system for in-training evaluation of residents in a laparoscopic educational program. Obstetrics \& Gynecology. 1997;90(1):148-52. 58. Garrity ML, Luiselli JK, McCollum SA. Effects of a supervisory intervention on assessment of interobserver agreement by educational service providers. Behavioral Interventions. 2008;23(2):105-12.

59. Gilbertson D, Witt JC, Singletary LL, VanDerHeyden A. Supporting Teacher Use of Interventions: Effects of Response Dependent Performance Feedback on Teacher Implementation of a Math Intervention. Journal of Behavioral Education. 2007;16(4):311-26. 60. Gordon M, Bose-Haider B. A novel system of prescribing feedback to reduce errors: A pilot study. International Journal of Risk \& Safety in Medicine. 2012;24(4):207-14.

61. Hagermoser Sanetti LM, Fallon LM, Collier-Meek MA. Increasing teacher treatment integrity through performance feedback provided by school personnel.Psychology in the Schools. 2013;50(2):134-50. 
This is the peer reviewed version of the following article: Mattick, K. , Brennan, N. , Briscoe, S. , Papoutsi, C. and Pearson, M. (2019), Optimising feedback for early career professionals: a scoping review and new framework. Med Educ, 53: 355-368, which has been published in final form at https://doi.org/10.1111/medu.13794. This article may be used for non-commercial purposes in accordance with Wiley Terms and Conditions for Use of Self-Archived Versions.

62. Helder OK, Kornelisse RF, Reiss IK, Ista E. Disinfection practices in intravenous drug administration. American Journal of Infection Control. 2016;44(6):721-3.

63. Hempel D, Pivetta E, Kimberly HH. Personalized peer-comparison feedback and its effect on emergency medicine resident ultrasound scan numbers. Critical Ultrasound Journal. 2014;6(1):1.

64. Hermsen ED, VanSchooneveld TC, Sayles H, Rupp ME. Implementation of a clinical decision support system for antimicrobial stewardship. Infection Control \& Hospital Epidemiology. 2012;33(4):412-5.

65. Horowitz CR, Chassin MR. Improving the quality of pneumonia care that patients experience. American Journal of Medicine. 2002;113(5):379-83.

66. Huber K, Zenilman J, Blanding R, Reuland C, Sood G. Real-time Direct Feedback Intervention to Improve and Sustain Hand Hygiene Practices in a Tertiary Care Academic Facility. 42nd Annual Conference Abstracts, APIC 2015, Nashville, TN June 2015. American Journal of Infection Control. 2015;43:S52-S3.

67. Konig C, Plank J, Augustin T, Habacher W, Beck P, Fruhwald T, et al. Effects of audit and feedback on professional practice in Geriatric Acute Care Units. European Geriatric Medicine. 2013;4(6):394-400.

68. Langston M. Effects of peer monitoring and peer feedback on hand hygiene in surgical intensive care unit and step-down units. Journal of Nursing Care Quality. 2011;26(1):49-53.

69. Luke MM, Alavosius M. Adherence with Universal Precautions after Immediate, Personalized Performance Feedback. Journal of Applied Behavior Analysis. 2011;44(4):967-71. 70. Marra AR, D'Arco C, Bravim BA, Martino MDV, Correa L, Silva CV, et al. Controlled trial measuring the effect of a feedback intervention on hand hygiene compliance in a step-down unit. Infection Control \& Hospital Epidemiology. 2008;29(8):730-5. 
This is the peer reviewed version of the following article: Mattick, K. , Brennan, N. , Briscoe, S. , Papoutsi, C. and Pearson, M. (2019), Optimising feedback for early career professionals: a scoping review and new framework. Med Educ, 53: 355-368, which has been published in final form at https://doi.org/10.1111/medu.13794. This article may be used for non-commercial purposes in accordance with Wiley Terms and Conditions for Use of Self-Archived Versions.

71. Mautone JA, Luiselli JK, Handler MW. Improving Implementation of Classroom Instruction through Teacher-Directed Behavioral Consultation: A Single-Case Demonstration. International Journal of Behavioral Consultation and Therapy. 2006;2(3):432-8.

72. McKenney ELW, Waldron N, Conroy M. The Effects of Training and Performance Feedback during Behavioral Consultation on General Education Middle School Teachers' Integrity to Functional Analysis Procedures. Journal of Educational \& Psychological Consultation. 2013;23(1):63-85.

73. Minor L, DuBard M, Luiselli JK. Improving integrity of direct-service practitioners through performance feedback and problem solving consultation. Behavioral Interventions. 2014;29(2):145-56.

74. Mouzakitis A, Codding RS, Tryon G. The Effects of Self-Monitoring and Performance Feedback on the Treatment Integrity of Behavior Intervention Plan Implementation and Generalization. Journal of Positive Behavior Interventions. 2015;17(4):223-34.

75. Noell GH, Witt JC, Gilbertson DN, Ranier DD, Freeland JT. Increasing teacher intervention implementation in general education settings through consultation and performance feedback. School Psychology Quarterly. 1997;12(1):77-88.

76. O'Horo JC, Omballi M, Tran TK, Jordan JP, Baumgardner DJ, Gennis MA. Effect of audit and feedback on improving handovers: a nonrandomized comparative study.[Erratum appears in J Grad Med Educ. 2012 Jun;4(2):271.

77. Pate PG, Storey DF, Baum DL. Implementation of an antimicrobial stewardship program at a 60-bed long-term acute care hospital. Infection Control \& Hospital Epidemiology. 2012;33(4):405-8

78. Pessoa-Silva CL, Hugonnet S, Pfister R, Touveneau S, Dharan S, Posfay-Barbe K, et al. Reduction of health care associated infection risk in neonates by successful hand hygiene promotion. Pediatrics. 2007;120(2):e382-90. 
This is the peer reviewed version of the following article: Mattick, K. , Brennan, N. , Briscoe, S. , Papoutsi, C. and Pearson, M. (2019), Optimising feedback for early career professionals: a scoping review and new framework. Med Educ, 53: 355-368, which has been published in final form at https://doi.org/10.1111/medu.13794. This article may be used for non-commercial purposes in accordance with Wiley Terms and Conditions for Use of Self-Archived Versions.

79. Proude EM, Conigrave KM, Britton A, Haber PS. Improving alcohol and tobacco history taking by junior medical officers. Alcohol \& Alcoholism. 2008;43(3):320-5.

80. Rathel JM. Effects of e-mailed specific performance feedback on induction level teachers' communication behaviors in classrooms for students with mild disabilities.

Dissertation Abstracts International Section A: Humanities and Social Sciences. 2009;69(7-

A):2671.

81. Rathel JM, Drasgow E, Brown WH, Marshall KJ. Increasing Induction-Level Teachers' Positive-to-Negative Communication Ratio and Use of Behavior-Specific Praise Through EMailed Performance Feedback and Its Effect on Students' Task Engagement. Journal of Positive Behavior Interventions. 2014;16(4):219-33.

82. Render ML, Hasselbeck R, Freyberg RW, Hofer TP, Sales AE, Almenoff PL. Reduction of central line infections in Veterans Administration intensive care units: an observational cohort using a central infrastructure to support learning and improvement. BMJ Quality \& Safety. 2011;20(8):725-32.

83. Rodriguez BJ, Loman SL, Horner RH. A preliminary analysis of the effects of coaching feedback on teacher implementation fidelity of first step to success. Behavior Analysis in Practice. 2009;2(2):11-21.

84. Sanetti LMH, Chafouleas SM, Fallon LM, Jaffrey R. Increasing Teachers' Adherence to a Classwide Intervention through Performance Feedback Provided by a School-Based Consultant: A Case Study. Journal of Educational \& Psychological Consultation. 2014;24(3):239-60.

85. Schwartzberg E, Rubinovich S, Hassin D, Haspel J, Ben-Moshe A, Oren M, et al. Developing and implementing a model for changing physicians' prescribing habits - the role of clinical pharmacy in leading the change. Journal of Clinical Pharmacy \& Therapeutics. 2006;31(2):179-85

86. Suhrheinrich JB. A Sustainable Model for Training Teachers to Use Pivotal Response Training: ProQuest LLC; 2010. 
This is the peer reviewed version of the following article: Mattick, K. , Brennan, N. , Briscoe, S. , Papoutsi, C. and Pearson, M. (2019), Optimising feedback for early career professionals: a scoping review and new framework. Med Educ, 53: 355-368, which has been published in final form at https://doi.org/10.1111/medu.13794. This article may be used for non-commercial purposes in accordance with Wiley Terms and Conditions for Use of Self-Archived Versions.

87. Sullivan KM, Suh S, Monk H, Chuo J. Personalised performance feedback reduces narcotic prescription errors in a NICU. BMJ Quality \& Safety. 2013;22(3):256-62.

88. Tang SYF, Chow AWK. Communicating feedback in teaching practice supervision in a learning-oriented field experience assessment framework. Teaching \& Teacher Education. 2007;23(7):1066-85.

89. Witt JC, Noell GH, LaFleur LH, Mortenson BP. Teacher use of interventions in general education settings: Measurement and analysis of the independent variable. Journal of Applied Behavior Analysis. 1997;30(4):693-6.

90. Zhu Y. The impact of performance feedback on treatment integrity and outcomes for a class-wide peer tutoring reading intervention. Dissertation Abstracts International Section A: Humanities and Social Sciences. 2015;75(11-A(E)).

91. Balas EA, Boren SA, Brown GD, Ewigman BG, Mitchell JA, Perkoff GT. Effect of physician profiling on utilization. Meta-analysis of randomized clinical trials. Journal of General Internal Medicine. 1996;11(10):584-90.

92. De Vos M, Graafmans W, Kooistra M, Meijboom B, Van Der Voort P, Westert G. Using quality indicators to improve hospital care: a review of the literature. International Journal for Quality in Health Care. 2009;21(2):119-29.

93. Dulko D. Audit and feedback as a clinical practice guideline implementation strategy: a model for acute care nurse practitioners. Worldviews on Evidence-Based Nursing. 2007;4(4):200-9.

94. Ista $\mathrm{E}$, van Dijk M, van Achterberg T. Do implementation strategies increase adherence to pain assessment in hospitals? A systematic review. International Journal of Nursing Studies. 2013;50(4):552-68.

95. Naikoba S, Hayward A. The effectiveness of interventions aimed at increasing handwashing in healthcare workers - a systematic review. Journal of Hospital Infection. 2001;47(3):173-80. 
This is the peer reviewed version of the following article: Mattick, K. , Brennan, N. , Briscoe, S. , Papoutsi, C. and Pearson, M. (2019), Optimising feedback for early career professionals: a scoping review and new framework. Med Educ, 53: 355-368, which has been published in final form at https://doi.org/10.1111/medu.13794. This article may be used for non-commercial purposes in accordance with Wiley Terms and Conditions for Use of Self-Archived Versions.

96. Noell GH, Gansle KA, Mevers JL, Knox RM, Mintz JC, Dahir A. Improving Treatment Plan Implementation in Schools: A Meta-Analysis of Single Subject Design Studies. Journal of Behavioral Education. 2014;23(1):168-91

97. Saedon H, Salleh S, Balakrishnan A, Imray CH, Saedon M. The role of feedback in improving the effectiveness of workplace based assessments: a systematic review. BMC Medical Education. 2012;12:25.

98. Solomon BG, Klein SA, Politylo BC. The Effect of Performance Feedback on Teachers' Treatment Integrity: A Meta-Analysis of the Single-Case Literature. School Psychology Review. 2012;41(2):160-75

99. Veloski J, Boex JR, Grasberger MJ, Evans A, Wolfson DB. Systematic Review of the Literature on Assessment, Feedback and Physicians' Clinical Performance: BEME Guide No. 7. Medical Teacher. 2006;28(2):117-28. 
This is the peer reviewed version of the following article: Mattick, K. , Brennan, N., Briscoe, S. , Papoutsi, C. and Pearson, M. (2019), Optimising feedback for early career professionals: a scoping review and new framework. Med Educ, 53: 355-368, which has been published in final form at https://doi.org/10.1111/medu.13794. This article may be used for non-commercial purposes in accordance with Wiley Terms and Conditions for Use of Self-Archived Versions.

\section{Box 1: Databases searched}

- MEDLINE, via Ovid

- MEDLINE-in-Process, via Ovid

- PsycINFO, via Ovid

- CINAHL, via EBSCO

- Education Research Complete, via EBSCO

- $\quad$ ERIC (which covers education), via EBSCO

- Cochrane Database of Systematic Reviews, via the Cochrane Library

- Social Science Citation Index (which covers sociology, business \& communication, law and nursing), via Thomson Reuters

- ASSIA (which covers nursing, mental health and other health services from a social science perspective), via ProQuest 
This is the peer reviewed version of the following article: Mattick, K. , Brennan, N. , Briscoe, S. , Papoutsi, C. and Pearson, M. (2019), Optimising feedback for early career professionals: a scoping review and new framework. Med Educ, 53: 355-368, which has been published in final form at https://doi.org/10.1111/medu.13794. This article may be used for non-commercial purposes in accordance with Wiley Terms and Conditions for Use of Self-Archived Versions.

\section{Table 1: Inclusion criteria}

\begin{tabular}{|c|c|c|}
\hline Stage & Category & Descriptor \\
\hline $\begin{array}{l}\text { Mapping \& } \\
\text { framework } \\
\text { development }\end{array}$ & $\begin{array}{l}\text { Empirical } \\
\text { research }\end{array}$ & $\begin{array}{l}\text { Articles that presented empirical research. Literature reviews were } \\
\text { only included if they had a clear and transparent methodology. } \\
\text { Articles were excluded if the abstract said nothing about data } \\
\text { collection, analysis or findings; or presented a collection of papers or } \\
\text { a book; or were primarily a description of an initiative or } \\
\text { intervention with no evidence of impact. }\end{array}$ \\
\hline $\begin{array}{l}\text { Mapping \& } \\
\text { framework } \\
\text { development }\end{array}$ & $\begin{array}{l}\text { Feedback to } \\
\text { early career } \\
\text { professional } \\
\text { (ECP) }\end{array}$ & $\begin{array}{l}\text { Articles that described feedback interventions from an external } \\
\text { source (e.g. senior, peer, patient) to an individual ECP. Articles were } \\
\text { included if ECPs formed (or were likely to form) a substantial } \\
\text { proportion of the study population. For example, specialist trainees } \\
\text { in medicine in the UK were excluded since they were more than two } \\
\text { years postgraduate but participants referred to as junior doctors, } \\
\text { house officers or residents were included unless it was clear that } \\
\text { they were >2 years post-graduation. Articles were excluded if they } \\
\text { focussed on feedback to teams rather than individuals; focussed on } \\
\text { feedback to managers about ECPs; focussed on self-assessment, } \\
\text { feedback to self or self-monitoring; focussed on ECPs giving } \\
\text { feedback to others; or focussed on feedback to paraprofessionals. }\end{array}$ \\
\hline $\begin{array}{l}\text { Mapping \& } \\
\text { framework } \\
\text { development }\end{array}$ & $\begin{array}{l}\text { Authentic } \\
\text { 'hot action' } \\
\text { workplace }\end{array}$ & $\begin{array}{l}\text { Articles that involved feedback interventions in authentic workplace } \\
\text { settings, which are comparable to a 'hot action' context (12). } \\
\text { Articles were excluded if they involved simulated practice; involved } \\
\text { community-based practice only e.g. general medical and dental } \\
\text { practice, outpatient clinics, pre-school teaching, kindergarten } \\
\text { teaching; involved abstracted, general or 'overall performance' } \\
\text { feedback rather than specific feedback relating to a discrete element } \\
\text { of authentic practice; involved feedback that was not given in the } \\
\text { setting where the work takes place (or close by) or by those who } \\
\text { would have close insights into the setting. Articles involving } \\
\text { feedback in verbal, written and electronic form were included. }\end{array}$ \\
\hline $\begin{array}{l}\text { Mapping \& } \\
\text { framework } \\
\text { development }\end{array}$ & $\begin{array}{l}\text { Learner } \\
\text { behaviour }\end{array}$ & $\begin{array}{l}\text { Articles that described feedback interventions that aimed to impact } \\
\text { on learner behaviours relevant to professional practice and/or } \\
\text { clinical workplace outcomes. Articles were excluded if they focussed } \\
\text { on satisfaction, knowledge, skills, or attendance at work only; or } \\
\text { focussed on the perceptions of ECPs without offering a perspective } \\
\text { on behaviour change or workplace results. }\end{array}$ \\
\hline $\begin{array}{l}\text { Mapping \& } \\
\text { framework } \\
\text { development }\end{array}$ & $\begin{array}{l}\text { Impact of } \\
\text { feedback }\end{array}$ & $\begin{array}{l}\text { Articles that focussed on the impact of the feedback intervention } \\
\text { rather than other aspects. For example, articles that focussed on } \\
\text { the feedback tool itself (e.g. reliability, validity, implementation) } \\
\text { were excluded. }\end{array}$ \\
\hline $\begin{array}{l}\text { Mapping \& } \\
\text { framework } \\
\text { development }\end{array}$ & $\begin{array}{l}\text { Relevant to } \\
\text { Research } \\
\text { Questions }\end{array}$ & $\begin{array}{l}\text { Articles that presented findings that had the potential to contribute } \\
\text { to this study's Research Questions. }\end{array}$ \\
\hline $\begin{array}{l}\text { Framework } \\
\text { development }\end{array}$ & $\begin{array}{l}\text { Detailed } \\
\text { focus on } \\
\text { feedback }\end{array}$ & $\begin{array}{l}\text { Articles whose major focus was the feedback process, especially in } \\
\text { relation to ECPs, and would therefore contribute substantially to } \\
\text { framework development }\end{array}$ \\
\hline
\end{tabular}


This is the peer reviewed version of the following article: Mattick, K. , Brennan, N. , Briscoe, S. , Papoutsi, C. and Pearson, M. (2019), Optimising feedback for early career professionals: a scoping review and new framework. Med Educ, 53: 355-368, which has been published in final form at https://doi.org/10.1111/medu.13794. This article may be used for non-commercial purposes in accordance with Wiley Terms and Conditions for Use of Self-Archived Versions.

\begin{tabular}{lll}
\hline $\begin{array}{l}\text { Framework } \\
\text { development }\end{array}$ & $\begin{array}{l}\text { Rich } \\
\text { contextual } \\
\text { detail }\end{array}$ & $\begin{array}{l}\text { Articles that had rich contextual details that enabled an } \\
\text { understanding of the important influences affecting feedback to } \\
\text { ECPs, and would therefore contribute substantially to framework } \\
\text { development }\end{array}$ \\
\hline
\end{tabular}


This is the peer reviewed version of the following article: Mattick, K. , Brennan, N. , Briscoe, S. , Papoutsi, C. and Pearson, M. (2019), Optimising feedback for early career professionals: a scoping review and new framework. Med Educ, 53: 355-368, which has been published in final form at https://doi.org/10.1111/medu.13794. This article may be used for non-commercial purposes in accordance with Wiley Terms and Conditions for Use of Self-Archived Versions.

Table 2: Total number of records and unique records

\begin{tabular}{ll}
\hline Database & Number of hits \\
\hline MEDLINE & 1607 \\
MEDLINE-in-Process & 181 \\
PsycINFO & 2422 \\
CINAHL & 801 \\
Cochrane Database of Systematic Reviews & 0 \\
Social Science Citation Index & 1363 \\
ASSIA & 265 \\
ERIC & 988 \\
Education Research Complete & 1049 \\
\hline Total number of records & $\mathbf{8 6 7 6}$ \\
\hline Duplicate records & 3629 \\
\hline Total number of unique records & $\mathbf{5 0 4 7}$ \\
\hline
\end{tabular}

Table 3: Empirical studies included in our literature review 
This is the peer reviewed version of the following article: Mattick, K., Brennan, N. Briscoe, S. , Papoutsi, C. and Pearson, M. (2019), Optimising feedback for early career professionals: a scoping review and new framework. Med Educ, 53: 355-368, which has been published in final form at https://doi.org/10.1111/medu.13794. This article may be used for non-commercial purposes in accordance with Wiley Terms and Conditions for Use of Self-Archived Versions.

\begin{tabular}{|c|c|c|c|c|c|c|c|c|c|c|c|}
\hline 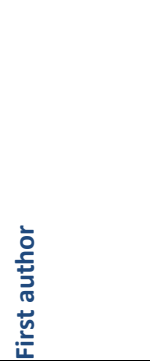 & 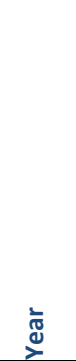 & 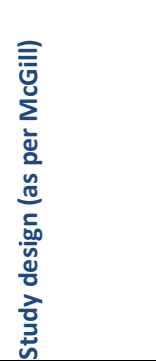 & 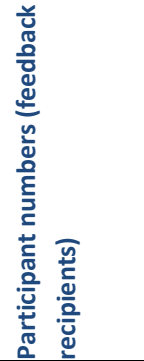 & 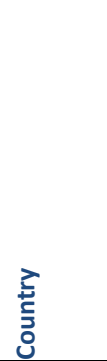 & 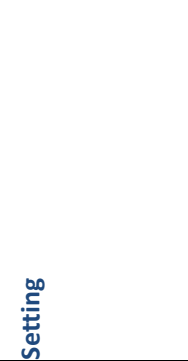 & $\frac{E}{\underline{\varepsilon}}$ & 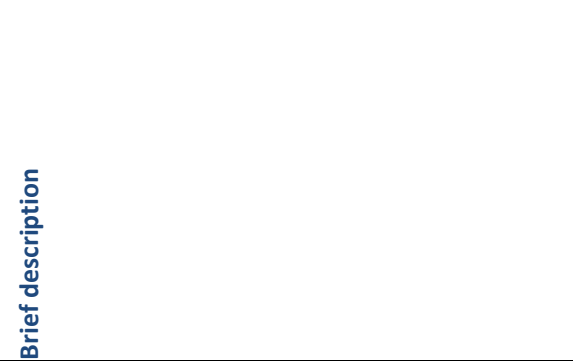 & 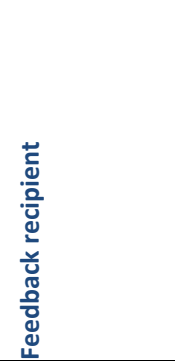 & 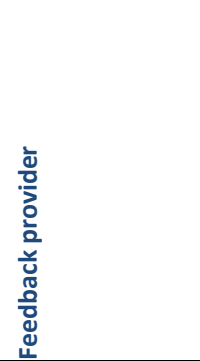 & 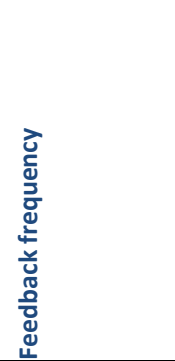 & 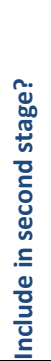 \\
\hline $\begin{array}{l}\text { Abu-Hanna } \\
\text { (40) }\end{array}$ & 2010 & $\begin{array}{l}\text { Quantitativ } \\
\text { e non- } \\
\text { randomised } \\
: \text { before and } \\
\text { after study }\end{array}$ & $\begin{array}{l}\text { Unclear } \\
\text { (ward- } \\
\text { round } \\
\text { team) }\end{array}$ & $\begin{array}{l}\text { Netherl } \\
\text { ands }\end{array}$ & $\begin{array}{l}\text { Hospital: one } \\
\text { Intensive Care } \\
\text { Unit }\end{array}$ & $\begin{array}{l}\text { To examine the impact of } \\
\text { providing feedback at ward } \\
\text { rounds on adherence to a local } \\
\text { mechanical ventilation policy. }\end{array}$ & $\begin{array}{l}\text { Feedback about adherence to the guideline } \\
\text { provided at daily ward rounds using a bedside } \\
\text { computerized decision support system. The } \\
\text { outcome measure was the percentage of } \\
\text { ventilation time in excess of the guideline's } \\
\text { recommendation and actual usage of the } \\
\text { feedback. }\end{array}$ & $\begin{array}{l}\text { ICU } \\
\text { physicians } \\
\text { and residents }\end{array}$ & $\begin{array}{l}\text { Computerized } \\
\text { decision } \\
\text { support system }\end{array}$ & Daily & No \\
\hline $\begin{array}{l}\text { Alagha } \\
\text { (41) }\end{array}$ & 2011 & $\begin{array}{l}\text { Quantitativ } \\
\text { e non- } \\
\text { randomised }\end{array}$ & $\begin{array}{l}\text { Unclear } \\
\text { (focus is } \\
\text { prescriptio } \\
\text { ns written } \\
\text { and } \\
\text { number of } \\
\text { patients) }\end{array}$ & Egypt & $\begin{array}{l}\text { Hospital: one } \\
\text { paediatric } \\
\text { Intensive Care } \\
\text { Unit }\end{array}$ & $\begin{array}{l}\text { To investigate the impact of } \\
\text { different measures, } \\
\text { implemented by clinical } \\
\text { pharmacists, on prescribing } \\
\text { error rates. }\end{array}$ & $\begin{array}{l}\text { Provided information. Changed drug chart } \\
\text { structure. Introduced orientation for new } \\
\text { residents. Gave residents feedback on errors via } \\
\text { individualized written reports. }\end{array}$ & $\begin{array}{l}\text { Residents } \\
\text { (junior } \\
\text { doctors) }\end{array}$ & $\begin{array}{l}\text { Clinical } \\
\text { pharmacist (in } \\
\text { writing). }\end{array}$ & $\begin{array}{l}\text { Throughout } \\
\text { postintervent } \\
\text { ion period }\end{array}$ & No \\
\hline $\begin{array}{l}\text { Baysari } \\
(30)\end{array}$ & 2013 & $\begin{array}{l}\text { Mixed } \\
\text { methods }\end{array}$ & $\begin{array}{l}36 \\
\text { prescribers }\end{array}$ & $\begin{array}{l}\text { Austral } \\
\text { ia }\end{array}$ & $\begin{array}{l}\text { Teaching } \\
\text { hospital }\end{array}$ & $\begin{array}{l}\text { To determine whether } \\
\text { providing individualised } \\
\text { feedback to doctors about } \\
\text { their recent compliance with } \\
\text { the hospital's antibiotic policy } \\
\text { improves compliance with the } \\
\text { policy. }\end{array}$ & $\begin{array}{l}\text { Audited to see where 'controlled' antimicrobial } \\
\text { prescribed without approval. Feedback letter } \\
\text { sent to named prescribers each week. }\end{array}$ & $\begin{array}{l}\text { Junior } \\
\text { doctors 1-9 } \\
\text { years into } \\
\text { training }\end{array}$ & $\begin{array}{l}\text { Professor of } \\
\text { Clinical } \\
\text { Pharmacology } \\
\text { via email }\end{array}$ & $\begin{array}{l}7 / 36 \text { received } \\
\text { multiple } \\
\text { letters }\end{array}$ & Yes \\
\hline $\begin{array}{l}\text { Boekeloo } \\
\text { (31) }\end{array}$ & 1990 & $\begin{array}{l}\text { Quantitativ } \\
\text { e } \\
\text { randomised } \\
\text { controlled: }\end{array}$ & $\begin{array}{l}29 \text { internal } \\
\text { medicine } \\
\text { interns }\end{array}$ & USA & $\begin{array}{l}\text { Hospital: } \\
\text { inpatient } \\
\text { internal }\end{array}$ & $\begin{array}{l}\text { To improve house staff } \\
\text { management of cholesterol } \\
\text { with inpatients. }\end{array}$ & $\begin{array}{l}\text { Checklist. Performance feedback summarised } \\
\text { intern's cholesterol management performance } \\
\text { compared with most up-to-date } \\
\text { recommendations. }\end{array}$ & Interns & $\begin{array}{l}\text { Specialist in } \\
\text { Preventative } \\
\text { Cardiology }\end{array}$ & $\begin{array}{l}\text { Multiple } \\
\text { times }\end{array}$ & Yes \\
\hline
\end{tabular}


This is the peer reviewed version of the following article: Mattick, K., Brennan, N. Briscoe, S. , Papoutsi, C. and Pearson, M. (2019), Optimising feedback for early career professionals: a scoping review and new framework. Med Educ, 53: 355-368, which has been published in final form at https://doi.org/10.1111/medu.13794. This article may be used for non-commercial purposes in accordance with Wiley Terms and Conditions for Use of Self-Archived Versions.

\begin{tabular}{|c|c|c|c|c|c|c|c|c|c|c|c|}
\hline & & $\begin{array}{l}\text { at individual } \\
\text { level }\end{array}$ & & & $\begin{array}{l}\text { medicine } \\
\text { service }\end{array}$ & & & & & & \\
\hline $\begin{array}{l}\text { Briere (42) } \\
\text { (thesis) }\end{array}$ & 2012 & Same study a & Briere 2015 & & & & & & & & No \\
\hline $\begin{array}{l}\text { Briere (43) } \\
\text { (publicatio } \\
\text { n) }\end{array}$ & 2015 & $\begin{array}{l}\text { Quantitativ } \\
\text { e non- } \\
\text { randomised }\end{array}$ & 3 & USA & $\begin{array}{l}\text { Elementary } \\
\text { school }\end{array}$ & $\begin{array}{l}\text { To investigate effects of a } \\
\text { within-school consultation } \\
\text { intervention provided by } \\
\text { veteran teachers, involving } \\
\text { self-management, structured } \\
\text { meetings, focused } \\
\text { performance feedback. }\end{array}$ & $\begin{array}{l}\text { Used a self-monitoring strategy. Consultation } \\
\text { meetings involved data review, performance } \\
\text { feedback, and goal setting. }\end{array}$ & $\begin{array}{l}\text { New teachers } \\
\text { with low } \\
\text { rates of } \\
\text { praise } \\
\text { feedback. }\end{array}$ & $\begin{array}{l}\text { Veteran } \\
\text { teachers }\end{array}$ & $\begin{array}{l}\text { Weekly for at } \\
\text { least six } \\
\text { weeks }\end{array}$ & No \\
\hline $\begin{array}{l}\text { Brinkman } \\
\text { (32) }\end{array}$ & 2007 & $\begin{array}{l}\text { Quantitativ } \\
\mathrm{e} \\
\text { randomised } \\
\text { controlled: } \\
\text { at individual } \\
\text { level }\end{array}$ & 36 & USA & $\begin{array}{l}\text { Children's } \\
\text { hospital }\end{array}$ & $\begin{array}{l}\text { To test whether multisource } \\
\text { feedback, including self- } \\
\text { coaching, improves resident } \\
\text { communication skills and } \\
\text { professionalism. }\end{array}$ & $\begin{array}{l}\text { Self-assessment. Feedback report about } \\
\text { baseline parent and nurse evaluations. Tailored } \\
\text { coaching session. }\end{array}$ & $\begin{array}{l}\text { First year } \\
\text { paediatric } \\
\text { residents }\end{array}$ & $\begin{array}{l}\text { Nurses and } \\
\text { parents }\end{array}$ & Once & Yes \\
\hline Brock (44) & 2002 & $\begin{array}{l}\text { Quantitativ } \\
\mathrm{e} \\
\text { randomised } \\
\text { controlled: } \\
\text { at group } \\
\text { level }\end{array}$ & $\begin{array}{l}92 \\
\text { healthcare } \\
\text { workers }\end{array}$ & USA & $\begin{array}{l}\text { Trauma centre: } \\
\text { ER and ICU }\end{array}$ & $\begin{array}{l}\text { To determine if participation in } \\
\text { performance feedback would } \\
\text { result in a statistically } \\
\text { significant improvement in } \\
\text { handwashing behaviours. }\end{array}$ & $\begin{array}{l}\text { Observed for handwashing behaviours. } \\
\text { Performance feedback via personal confidential } \\
\text { card identifying rate of handwashing and } \\
\text { handwashing technique. }\end{array}$ & $\begin{array}{l}\text { Healthcare } \\
\text { workers }\end{array}$ & $\begin{array}{l}\text { Researcher via } \\
\text { confidential } \\
\text { written card }\end{array}$ & $\begin{array}{l}\text { One off } \\
\text { feedback, } \\
\text { based on } \\
\text { observation } \\
\text { of multiple } \\
\text { HW events. }\end{array}$ & No \\
\hline Chern (45) & 2005 & $\begin{array}{l}\text { Quantitativ } \\
\text { e non- } \\
\text { randomised }\end{array}$ & Unclear & Taiwan & $\begin{array}{l}\text { Hospital: } \\
\text { emergency } \\
\text { department }\end{array}$ & $\begin{array}{l}\text { To evaluate what effects a } \\
\text { quality improvement initiative } \\
\text { with feedback from telephone } \\
\text { follow-up and teaching would } \\
\text { have on adverse outcomes. }\end{array}$ & $\begin{array}{l}\text { Direct feedback on patient outcomes via one-to- } \\
\text { one conversation within } 2 \text { days. Action } \\
\text { planning. }\end{array}$ & $\begin{array}{l}\text { Treating } \\
\text { clinician }\end{array}$ & $\begin{array}{l}\text { Faculty } \\
\text { investigator }\end{array}$ & $\begin{array}{l}\text { Unclear but } \\
\text { presumably } \\
\text { could receive } \\
\text { feedback } \\
\text { more than } \\
\text { once. }\end{array}$ & No \\
\hline Clay (33) & 2007 & $\begin{array}{l}\text { Quantitativ } \\
\text { e } \\
\text { randomised } \\
\text { controlled: }\end{array}$ & 18 & USA & $\begin{array}{l}\text { Hospital: } \\
\text { medical ICU }\end{array}$ & $\begin{array}{l}\text { To develop an assessment tool } \\
\text { for bedside teaching in the } \\
\text { intensive care unit (ICU) that } \\
\text { provides feedback to residents }\end{array}$ & $\begin{array}{l}\text { Residents were evaluated by nurse, fellows, and } \\
\text { faculty. }\end{array}$ & Residents & Fellows & Multiple & Yes \\
\hline
\end{tabular}


This is the peer reviewed version of the following article: Mattick, K. Brennan, N. Briscoe, S. , Papoutsi, C. and Pearson, M. (2019), Optimising feedback for early career professionals: a scoping review and new framework. Med Educ, 53: 355-368, which has been published in final form at https://doi.org/10.1111/medu.13794. This article may be used for non-commercial purposes in accordance with Wiley Terms and Conditions for Use of Self-Archived Versions.

\begin{tabular}{|c|c|c|c|c|c|c|c|c|c|c|c|}
\hline & & $\begin{array}{l}\text { at rotation } \\
\text { level }\end{array}$ & & & & $\begin{array}{l}\text { about their performance } \\
\text { compared with clinical best } \\
\text { practices. }\end{array}$ & & & & & \\
\hline $\begin{array}{l}\text { Codding } \\
\text { (46) }\end{array}$ & 2005 & $\begin{array}{l}\text { Quantitativ } \\
\text { e non- } \\
\text { randomised }\end{array}$ & 5 & USA & $\begin{array}{l}\text { Private school: } \\
\text { students with } \\
\text { acquired brain } \\
\text { injury }\end{array}$ & $\begin{array}{l}\text { To evaluate the effects of } \\
\text { performance feedback on the } \\
\text { percentage of antecedent and } \\
\text { consequence components } \\
\text { implemented correctly during } \\
\text { 1-hr observation sessions. }\end{array}$ & $\begin{array}{l}\text { Proportion of correct implementation of } \\
\text { student's behaviour support plans calculated. } \\
\text { Performance feedback given. }\end{array}$ & $\begin{array}{l}\text { Special needs } \\
\text { teachers }\end{array}$ & Investigator & Multiple & No \\
\hline Colvin (47) & 2009 & $\begin{array}{l}\text { Quantitativ } \\
\text { e non- } \\
\text { randomised }\end{array}$ & 1 & USA & $\begin{array}{l}\text { Suburban high } \\
\text { school }\end{array}$ & $\begin{array}{l}\text { To explore the relevance and } \\
\text { effectiveness of classroom } \\
\text { observation and performance } \\
\text { feedback that focused on the } \\
\text { relations among classroom } \\
\text { instructional settings, } \\
\text { instructional practice, and } \\
\text { classroom student behaviour. }\end{array}$ & $\begin{array}{l}\text { Observations of classroom teaching. Summary } \\
\text { tables of teaching and student behaviours. } \\
\text { Teacher and observer analysed data and } \\
\text { developed an action plan. }\end{array}$ & Teacher & Investigator & Three times & No \\
\hline $\begin{array}{l}\text { Cuticelli } \\
(48)\end{array}$ & 2016 & $\begin{array}{l}\text { Quantitativ } \\
\text { e non- } \\
\text { randomised }\end{array}$ & 6 & USA & Public school & $\begin{array}{l}\text { To explore whether providing } \\
\text { teachers with performance } \\
\text { feedback can improve quality } \\
\text { of instruction by increasing the } \\
\text { numbers of Opportunities To } \\
\text { Respond delivered during Tier } \\
1 \text { reading instruction. }\end{array}$ & $\begin{array}{l}\text { Teacher observations. Number of opportunities } \\
\text { to respond were counted. Performance } \\
\text { feedback with teachers provided with graphic } \\
\text { and oral feedback. }\end{array}$ & $\begin{array}{l}\text { Teachers: } 3 \\
\text { kindergarten, } \\
3 \text { first-grade. }\end{array}$ & $\begin{array}{l}\text { Doctoral } \\
\text { students } \\
\text { (educational } \\
\text { psychology) }\end{array}$ & Multiple & No \\
\hline $\begin{array}{l}\text { DiGennaro } \\
(49)\end{array}$ & 2007 & $\begin{array}{l}\text { Quantitativ } \\
\text { e non- } \\
\text { randomised }\end{array}$ & 4 & USA & $\begin{array}{l}\text { School for } \\
\text { students with } \\
\text { brain injuries }\end{array}$ & $\begin{array}{l}\text { To examine the extent to } \\
\text { which treatment integrity of } 4 \\
\text { teachers was affected by goal } \\
\text { setting, performance feedback } \\
\text { regarding student or teacher } \\
\text { performance, and a meeting } \\
\text { cancellation contingency. }\end{array}$ & $\begin{array}{l}\text { Teacher training to address student problem } \\
\text { behaviour. Goal setting for student behaviour, } \\
\text { with daily written feedback on student } \\
\text { performance and/or their accuracy in } \\
\text { implementing intervention. }\end{array}$ & $\begin{array}{l}\text { Struggling } \\
\text { special } \\
\text { education } \\
\text { teachers }\end{array}$ & $\begin{array}{l}\text { Education } \\
\text { consultant }\end{array}$ & $\begin{array}{l}\text { Multiple } \\
\text { (daily) }\end{array}$ & No \\
\hline $\begin{array}{l}\text { Digennaro- } \\
\text { Reed (50) }\end{array}$ & 2010 & $\begin{array}{l}\text { Quantitativ } \\
\text { e non- } \\
\text { randomised }\end{array}$ & 3 & USA & $\begin{array}{l}\text { School for } \\
\text { students with }\end{array}$ & $\begin{array}{l}\text { To examine the effects of } \\
\text { individualized video modelling } \\
\text { on the accurate }\end{array}$ & $\begin{array}{l}\text { Participants viewed individualized instructional } \\
\text { video of experienced teacher demonstrating }\end{array}$ & $\begin{array}{l}\text { Special needs } \\
\text { teachers }\end{array}$ & Experimenter & Multiple & No \\
\hline
\end{tabular}


This is the peer reviewed version of the following article: Mattick, K., Brennan, N. Briscoe, S. , Papoutsi, C. and Pearson, M. (2019), Optimising feedback for early career professionals: a scoping review and new framework. Med Educ, 53: 355-368, which has been published in final form at https://doi.org/10.1111/medu.13794. This article may be used for non-commercial purposes in accordance with Wiley Terms and Conditions for Use of Self-Archived Versions.

\begin{tabular}{|c|c|c|c|c|c|c|c|c|c|c|c|}
\hline & & & & & $\begin{array}{l}\text { developmental } \\
\text { disorders }\end{array}$ & $\begin{array}{l}\text { implementation of behavioural } \\
\text { interventions. }\end{array}$ & $\begin{array}{l}\text { accurate implementation. Performance } \\
\text { feedback prior to the video. }\end{array}$ & & & & \\
\hline $\begin{array}{l}\text { Duncan } \\
\text { (51) }\end{array}$ & 2013 & $\begin{array}{l}\text { Quantitativ } \\
\text { e non- } \\
\text { randomised }\end{array}$ & 3 & USA & $\begin{array}{l}\text { Public schools: } \\
\text { general } \\
\text { education }\end{array}$ & $\begin{array}{l}\text { To examine effects of } \\
\text { generalization training with } \\
\text { goal setting and a feedback } \\
\text { note on teachers' specific } \\
\text { labelled praise (SLP) toward } \\
\text { target and nontarget students. }\end{array}$ & $\begin{array}{l}\text { Teacher instruction, role playing, practice, and } \\
\text { feedback. Goal setting for delivery of SLP to the } \\
\text { target student. Performance feedback relating } \\
\text { to goal. Training to generalise intervention. }\end{array}$ & Teachers & $\begin{array}{l}\text { Doctoral } \\
\text { student in } \\
\text { school } \\
\text { psychology }\end{array}$ & $\begin{array}{l}\text { Multiple via } \\
\text { feedback } \\
\text { note }\end{array}$ & No \\
\hline $\begin{array}{l}\text { Eveillard } \\
(52)\end{array}$ & 2011 & $\begin{array}{l}\text { Quantitativ } \\
\text { e non- } \\
\text { randomised }\end{array}$ & 75 & France & $\begin{array}{l}\text { Healthcare: } \\
\text { four settings } \\
\text { (acute-care } \\
\text { geriatric wards, } \\
\text { skilled nursing } \\
\text { homes, physical } \\
\text { rehabilitation } \\
\text { units) }\end{array}$ & $\begin{array}{l}\text { To assess the impact of a multi- } \\
\text { faceted training program on } \\
\text { the compliance with hand } \\
\text { hygiene and gloving practices. }\end{array}$ & $\begin{array}{l}\text { Intervention program including performance } \\
\text { feedback, three training sessions, assessment of } \\
\text { hand hygiene performance. }\end{array}$ & $\begin{array}{l}\text { Healthcare } \\
\text { worker }\end{array}$ & Researchers & One off & No \\
\hline Fakih (53) & 2012 & $\begin{array}{l}\text { Quantitativ } \\
\text { e } \\
\text { randomised } \\
\text { controlled: } \\
\text { at unit level }\end{array}$ & 180 nurses & USA & $\begin{array}{l}\text { Teaching } \\
\text { hospital: } 10 \\
\text { adult wards }\end{array}$ & $\begin{array}{l}\text { To evaluate effect of education } \\
\text { and feedback on Peripheral } \\
\text { Venous Catheter care and } \\
\text { infectious complications over a } \\
3 \text { month intervention. }\end{array}$ & $\begin{array}{l}\text { Education, educational materials (posters and } \\
\text { cards), performance feedback, twice-monthly } \\
\text { audits, monthly reports to nurse managers }\end{array}$ & Nurses & Research nurses & $\begin{array}{l}\text { Twice- } \\
\text { monthly } \\
\text { audits }\end{array}$ & No \\
\hline Feely (54) & 1990 & $\begin{array}{l}\text { Quantitativ } \\
\text { e non- } \\
\text { randomised }\end{array}$ & $\begin{array}{l}\text { Unclear } \\
\text { (focus on } \\
\text { events } \\
\text { rather than } \\
\text { people) }\end{array}$ & Ireland & Hospital & $\begin{array}{l}\text { The effects of introducing a } \\
\text { hospital formulary alone and } \\
\text { with active intervention were } \\
\text { compared prospectively with } \\
\text { regard to drug costs and the } \\
\text { quality of prescribing. }\end{array}$ & $\begin{array}{l}\text { Feedback on prescribing habits. Peer } \\
\text { comparison. Information on drugs. }\end{array}$ & $\begin{array}{l}\text { Prescribers } \\
\text { and senior } \\
\text { consultants }\end{array}$ & Unclear & Multiple & No \\
\hline $\begin{array}{l}\text { Frenzel } \\
(55)\end{array}$ & 2010 & $\begin{array}{l}\text { Quantitativ } \\
\text { e non- } \\
\text { randomised }\end{array}$ & $\begin{array}{l}\text { Unclear } \\
(23,279 \\
\text { anaesthetic } \\
\text { events) }\end{array}$ & USA & $\begin{array}{l}\text { Hospital: cancer } \\
\text { centre }\end{array}$ & $\begin{array}{l}\text { To compare effects of } \\
\text { continuing medical education } \\
\text { alone, with one off feedback, } \\
\text { and with ongoing feedback on } \\
\text { postoperative nausea and } \\
\text { vomiting prophylaxis guideline } \\
\text { compliance. }\end{array}$ & $\begin{array}{l}\text { Analysed guideline compliance of } 23,279 \\
\text { anaesthetics. Individual performance feedback } \\
\text { compared to peers. }\end{array}$ & $\begin{array}{l}\text { Individual } \\
\text { clinicians }\end{array}$ & $\begin{array}{l}\text { Researcher, via } \\
\text { confidential } \\
\text { individual } \\
\text { reports. }\end{array}$ & $\begin{array}{l}\text { Once in one } \\
\text { condition; } \\
\text { multiple } \\
\text { times in } \\
\text { another. }\end{array}$ & No \\
\hline
\end{tabular}


This is the peer reviewed version of the following article: Mattick, K., Brennan, N. Briscoe, S. , Papoutsi, C. and Pearson, M. (2019), Optimising feedback for early career professionals: a scoping review and new framework. Med Educ, 53: 355-368, which has been published in final form at https://doi.org/10.1111/medu.13794. This article may be used for non-commercial purposes in accordance with Wiley Terms and Conditions for Use of Self-Archived Versions.

\begin{tabular}{|c|c|c|c|c|c|c|c|c|c|c|c|}
\hline Fuller (56) & 2012 & $\begin{array}{l}\text { Quantitativ } \\
\text { e } \\
\text { randomised } \\
\text { controlled: } \\
\text { stepped } \\
\text { wedge } \\
\text { cluster RCT }\end{array}$ & $\begin{array}{l}\text { Unclear (33 } \\
\text { wards in } 16 \\
\text { hospitals) }\end{array}$ & UK & $\begin{array}{l}\text { Hospitals: } 33 \\
\text { wards }\end{array}$ & $\begin{array}{l}\text { To determine the effectiveness } \\
\text { of a feedback intervention to } \\
\text { improve hand-hygiene } \\
\text { compliance. }\end{array}$ & $\begin{array}{l}\text { Repeating } 4 \text { week cycle ( } 20 \text { minutes per week) of } \\
\text { observation, feedback and personalised action } \\
\text { planning, recorded on forms. Observed impact } \\
\text { on hand hygiene compliance. }\end{array}$ & $\begin{array}{l}\text { Healthcare } \\
\text { workers } \\
\text { including } \\
\text { nurses and } \\
\text { doctors. }\end{array}$ & $\begin{array}{l}\text { An allocated } \\
\text { "ward } \\
\text { coordinator", a } \\
\text { junior ward } \\
\text { sister or } \\
\text { infection } \\
\text { control link } \\
\text { nurse. }\end{array}$ & Multiple & Yes \\
\hline Fung (57) & 1997 & $\begin{array}{l}\text { Quantitativ } \\
\text { e non- } \\
\text { randomised }\end{array}$ & 16 & Canada & $\begin{array}{l}\text { Hospital: } \\
\text { Department of } \\
\text { Obstetrics \& } \\
\text { Gynaecology }\end{array}$ & $\begin{array}{l}\text { To describe initial experience } \\
\text { with a computerized } \\
\text { telecommunication system to } \\
\text { record resident performance of } \\
\text { laparoscopic surgery. }\end{array}$ & $\begin{array}{l}\text { After a laparoscopic procedure, surgeon and } \\
\text { resident telephone a toll-free number, respond } \\
\text { to pre-recorded statements using a Likert scale } \\
\text { and comment on response to events during the } \\
\text { surgery. Feedback made available to residents. }\end{array}$ & Residents & Surgeons & Multiple & No \\
\hline $\begin{array}{l}\text { Garrity } \\
\text { (58) }\end{array}$ & 2008 & $\begin{array}{l}\text { Quantitativ } \\
\text { e non- } \\
\text { randomised }\end{array}$ & 8 & USA & $\begin{array}{l}\text { School for } \\
\text { children with } \\
\text { developmental } \\
\text { disabilities }\end{array}$ & $\begin{array}{l}\text { To evaluate a supervisory } \\
\text { intervention to increase the } \\
\text { frequency of inter-observer } \\
\text { agreement assessments } \\
\text { performed by educational } \\
\text { staff. }\end{array}$ & $\begin{array}{l}\text { Intervention components included action } \\
\text { directives, strategic posting of inter-observer } \\
\text { agreement recording forms, and performance } \\
\text { feedback (positive reinforcement and } \\
\text { correction). }\end{array}$ & Teachers & Supervisors & Every week & No \\
\hline $\begin{array}{l}\text { Gilbertson } \\
\text { (59) }\end{array}$ & 2007 & $\begin{array}{l}\text { Quantitativ } \\
\text { e non- } \\
\text { randomised }\end{array}$ & 5 & USA & $\begin{array}{l}\text { Elementary } \\
\text { school: } 5 \\
\text { general } \\
\text { education } \\
\text { classrooms }\end{array}$ & $\begin{array}{l}\text { To examine the integrity of } \\
\text { teachers' implementation of a } \\
\text { peer tutoring intervention for } \\
\text { five students referred for } \\
\text { consultation and intervention } \\
\text { due to academic concerns. }\end{array}$ & $\begin{array}{l}\text { Intervention comprised: verbal training, faded 3- } \\
\text { criteria } \\
\text { classroom training, and response-dependent } \\
\text { performance feedback. }\end{array}$ & Teachers & Consultant & $\begin{array}{l}\text { Multiple - any } \\
\text { time }<100 \% \\
\text { compliance }\end{array}$ & No \\
\hline $\begin{array}{l}\text { Gordon } \\
(60)\end{array}$ & 2012 & $\begin{array}{l}\text { Quantitativ } \\
\text { e non- } \\
\text { randomised }\end{array}$ & 26 & UK & $\begin{array}{l}\text { Hospital: } 1 \\
\text { inpatient } \\
\text { paediatric unit }\end{array}$ & $\begin{array}{l}\text { To explore the introduction of } \\
\text { a departmental prescribing } \\
\text { feedback system designed to } \\
\text { provide contemporaneous } \\
\text { prescribing feedback within the } \\
\text { context of shift working on } \\
\text { prescribing errors and safety } \\
\text { attitudes. }\end{array}$ & $\begin{array}{l}\text { Intervention comprised } 3 \text { weekly assessments of } \\
\text { prescribing errors over a } 3 \text { month period; } \\
\text { followed by feedback via a poster and emails to } \\
\text { staff, giving general and anonymous } \\
\text { personalised feedback. }\end{array}$ & $\begin{array}{l}\text { Prescribers } \\
\text { (paediatric } \\
\text { medical staff) }\end{array}$ & Unclear & Multiple & Yes \\
\hline
\end{tabular}


This is the peer reviewed version of the following article: Mattick, K., Brennan, N. Briscoe, S. , Papoutsi, C. and Pearson, M. (2019), Optimising feedback for early career professionals: a scoping review and new framework. Med Educ, 53: 355-368, which has been published in final form at https://doi.org/10.1111/medu.13794. This article may be used for non-commercial purposes in accordance with Wiley Terms and Conditions for Use of Self-Archived Versions.

\begin{tabular}{|c|c|c|c|c|c|c|c|c|c|c|c|}
\hline $\begin{array}{l}\text { Hagermos } \\
\text { er (61) }\end{array}$ & 2013 & $\begin{array}{l}\text { Quantitativ } \\
\text { e non- } \\
\text { randomised }\end{array}$ & 5 & $\begin{array}{l}\text { USA } \\
\text { (NE) }\end{array}$ & $\begin{array}{l}\text { Middle school } \\
\text { (grades 6-8) }\end{array}$ & $\begin{array}{l}\text { To explore whether } \\
\text { performance feedback } \\
\text { effectively increases teachers' } \\
\text { treatment } \\
\text { integrity when implementing a } \\
\text { classwide, team-based } \\
\text { contingency management } \\
\text { intervention. }\end{array}$ & $\begin{array}{l}\text { Training, then no performance feedback phase, } \\
\text { followed by a performance feedback phase as } \\
\text { needed. }\end{array}$ & Teachers & $\begin{array}{l}\text { Internal } \\
\text { Consultants } \\
\text { (school social } \\
\text { worker, special } \\
\text { education } \\
\text { teacher) }\end{array}$ & $\begin{array}{l}\text { Multiple, } \\
\text { responsive to } \\
\text { need. }\end{array}$ & No \\
\hline $\begin{array}{l}\text { Hadjianast } \\
\text { assiou (34) }\end{array}$ & 2001 & $\begin{array}{l}\text { Quantitativ } \\
\text { e non- } \\
\text { randomised }\end{array}$ & 11 & UK & $\begin{array}{l}\text { Hospital: } \\
\text { Accident \& } \\
\text { Emergency } \\
\text { department }\end{array}$ & $\begin{array}{l}\text { To compare personal, peer- } \\
\text { comparison feedback, to the } \\
\text { 'conventional' departmental } \\
\text { one. }\end{array}$ & $\begin{array}{l}\text { Audit of documentation process, then three sets } \\
\text { of patient presentations with no feedback, } \\
\text { personal peer comparison feedback, and } \\
\text { average departmental feedback applied } \\
\text { respectively, then re-audit. }\end{array}$ & $\begin{array}{l}\text { Senior house } \\
\text { officers }\end{array}$ & $\begin{array}{l}\text { Unclear } \\
\text { (written) }\end{array}$ & $\begin{array}{l}\text { Once for each } \\
\text { type }\end{array}$ & No \\
\hline Helder (62) & 2016 & $\begin{array}{l}\text { Quantitativ } \\
\text { e } \\
\text { randomised } \\
\text { controlled: } \\
\text { cluster }\end{array}$ & $\begin{array}{l}\text { Unclear } \\
\text { (799 } \\
\text { observation } \\
\text { s) }\end{array}$ & $\begin{array}{l}\text { Netherl } \\
\text { ands }\end{array}$ & $\begin{array}{l}\text { Hospital: } 3 \\
\text { neonatal/paedi } \\
\text { atric units }\end{array}$ & $\begin{array}{l}\text { To compare adherence to } \\
\text { intravenous (IV) preparation } \\
\text { and disinfection protocols } \\
\text { before and after the } \\
\text { introduction of mutual collegial } \\
\text { feedback. }\end{array}$ & $\begin{array}{l}\text { Education, brochure distribution and mutual } \\
\text { feedback between colleagues. }\end{array}$ & Nursing staff & Nursing staff & Multiple & No \\
\hline $\begin{array}{l}\text { Hempel } \\
(63)\end{array}$ & 2014 & $\begin{array}{l}\text { Quantitativ } \\
\text { e non- } \\
\text { randomised } \\
\text { : before and } \\
\text { after }\end{array}$ & 44 & USA & $\begin{array}{l}\text { Hospital: } \\
\text { emergency } \\
\text { medicine }\end{array}$ & $\begin{array}{l}\text { To evaluate if Clinician- } \\
\text { Performed Ultrasound scan } \\
\text { numbers improve after } \\
\text { residents are provided with a } \\
\text { personalized peer-comparison } \\
\text { feedback. }\end{array}$ & $\begin{array}{l}\text { Personalized peer-comparison feedback sent by } \\
\text { email and letter, comparing individual resident } \\
\text { ultrasound numbers with their peer group. }\end{array}$ & $\begin{array}{l}\text { Emergency } \\
\text { medicine } \\
\text { residents (all } \\
\text { in PGY-2 } \\
\text { through PGY- } \\
\text { 4). }\end{array}$ & Unclear & Once & Yes \\
\hline $\begin{array}{l}\text { Hermsen } \\
(64)\end{array}$ & 2012 & $\begin{array}{l}\text { Quantitativ } \\
\text { e non- } \\
\text { randomised } \\
\text { : before and } \\
\text { after }\end{array}$ & $\begin{array}{l}\text { Unclear } \\
(10,545 \\
\text { alerts })\end{array}$ & USA & Hospital & $\begin{array}{l}\text { To evaluate impact of a Clinical } \\
\text { Decision Support System on } \\
\text { performance of prospective } \\
\text { audit with intervention and } \\
\text { feedback. }\end{array}$ & $\begin{array}{l}\text { Implemented a Clinical Decision Support System } \\
\text { linked to an Antimicrobial Stewardship } \\
\text { Programme. Evaluated the number of } \\
\text { intervention attempts in the period before and } \\
\text { after the introduction of the Clinical Decision } \\
\text { Support System. }\end{array}$ & Unclear & $\begin{array}{l}\text { Clinical Decision } \\
\text { Support System } \\
\text { (via alerts) }\end{array}$ & Variable & No \\
\hline $\begin{array}{l}\text { Holmboe } \\
\text { (35) }\end{array}$ & 1998 & $\begin{array}{l}\text { Quantitativ } \\
\text { e non- } \\
\text { randomised }\end{array}$ & $\begin{array}{l}\text { Unclear } \\
(280\end{array}$ & USA & $\begin{array}{l}\text { Hospital: } \\
\text { general internal } \\
\text { medicine clinic }\end{array}$ & $\begin{array}{l}\text { To examine the effect of an } \\
\text { intervention using medical } \\
\text { record audits and }\end{array}$ & $\begin{array}{l}\text { Audited medical records and provided written } \\
\text { summary of performance (\% appropriately } \\
\text { performed) for three preventative health } \\
\text { interventions, then reviewed medical records to }\end{array}$ & $\begin{array}{l}\text { Residents in } \\
\text { general }\end{array}$ & $\begin{array}{l}\text { Auditors } \\
\text { (internists). }\end{array}$ & Multiple & No \\
\hline
\end{tabular}


This is the peer reviewed version of the following article: Mattick, K. Brennan, N. Briscoe, S. , Papoutsi, C. and Pearson, M. (2019), Optimising feedback for early career professionals: a scoping review and new framework. Med Educ, 53: 355-368, which has been published in final form at https://doi.org/10.1111/medu.13794. This article may be used for non-commercial purposes in accordance with Wiley Terms and Conditions for Use of Self-Archived Versions.

\begin{tabular}{|c|c|c|c|c|c|c|c|c|c|c|c|}
\hline & & $\begin{array}{l}\text { : before and } \\
\text { after }\end{array}$ & $\begin{array}{l}\text { medical } \\
\text { records) }\end{array}$ & & & $\begin{array}{l}\text { individualised feedback on } \\
\text { compliance with guidelines. }\end{array}$ & $\begin{array}{l}\text { see if any impact on other non-targeted } \\
\text { interventions. }\end{array}$ & $\begin{array}{l}\text { internal } \\
\text { medicine }\end{array}$ & & & \\
\hline $\begin{array}{l}\text { Horowitz } \\
(65)\end{array}$ & 2002 & $\begin{array}{l}\text { Quantitativ } \\
\text { e non- } \\
\text { randomised } \\
\text { : before and } \\
\text { after }\end{array}$ & Unclear & USA & $\begin{array}{l}\text { Hospital } \\
\text { with a four-year } \\
\text { Emergency } \\
\text { Medicine } \\
\text { residency } \\
\text { program }\end{array}$ & $\begin{array}{l}\text { To improve inpatients' } \\
\text { knowledge/experience of } \\
\text { community-acquired } \\
\text { pneumonia care, and decrease } \\
\text { unnecessary time on } \\
\text { intravenous antibiotics and } \\
\text { days in hospital, via a feedback } \\
\text { intervention to healthcare } \\
\text { staff. }\end{array}$ & $\begin{array}{l}\text { Guideline dissemination, education sessions for } \\
\text { physicians and nurses (lectures, individualised } \\
\text { data, peer discussions), educational brochure for } \\
\text { patients from nurses }\end{array}$ & $\begin{array}{l}\text { Attending } \\
\text { physicians } \\
\text { and house } \\
\text { staff, nurses } \\
\text { and social } \\
\text { workers }\end{array}$ & Unclear & Unclear & No \\
\hline Huber (66) & 2015 & $\begin{array}{l}\text { Quantitativ } \\
\text { e non- } \\
\text { randomised }\end{array}$ & Unclear & USA & Hospital & $\begin{array}{l}\text { To examine impact of a staff } \\
\text { member responsible for } \\
\text { feedback delivery on hand } \\
\text { hygiene compliance. }\end{array}$ & $\begin{array}{l}\text { Staff member appointed. Evaluation by 'secret } \\
\text { shopper' observation and feedback from } \\
\text { colleagues. }\end{array}$ & $\begin{array}{l}\text { All staff in } \\
\text { acute care } \\
\text { facility }\end{array}$ & Secret shopper & Unclear & No \\
\hline Konig (67) & 2013 & $\begin{array}{l}\text { Quantitativ } \\
\text { e non- } \\
\text { randomised } \\
\text { : before and } \\
\text { after }\end{array}$ & $\begin{array}{l}\text { Unclear } \\
(22,279 \\
\text { patient } \\
\text { data } \\
\text { records) }\end{array}$ & Austria & $\begin{array}{l}\text { Hospital: } 18 \\
\text { Geriatric Acute } \\
\text { Care Units }\end{array}$ & $\begin{array}{l}\text { To evaluate the effects of audit } \\
\text { and feedback on service } \\
\text { delivery and patient } \\
\text { functioning. }\end{array}$ & $\begin{array}{l}\text { Standardised documentation and introduced } \\
\text { web-based performance feedback with peer } \\
\text { comparison reports. Themes in feedback } \\
\text { addressed at local and regional meetings. }\end{array}$ & $\begin{array}{l}\text { Geriatric } \\
\text { acute care } \\
\text { unit staff }\end{array}$ & $\begin{array}{l}\text { Online system } \\
\text { (individual) and } \\
\text { meetings } \\
\text { (general) }\end{array}$ & $\begin{array}{l}\text { Feedback } \\
\text { reports every } \\
6 \text { months }\end{array}$ & No \\
\hline $\begin{array}{l}\text { Langston } \\
(68)\end{array}$ & 2011 & $\begin{array}{l}\text { Quantitativ } \\
\text { e non- } \\
\text { randomised } \\
\text { : before and } \\
\text { after }\end{array}$ & $\begin{array}{l}\text { Unclear } \\
\text { (428 audits) }\end{array}$ & USA & $\begin{array}{l}\text { University } \\
\text { hospital: } \\
\text { surgery } \\
\text { intensive care, } \\
\text { neurosurgery } \\
\text { intensive } \\
\text { care, and } \\
\text { surgical } \\
\text { intermediate } \\
\text { care units }\end{array}$ & $\begin{array}{l}\text { To increase hand hygiene } \\
\text { compliance through general } \\
\text { and individual feedback to } \\
\text { staff. }\end{array}$ & $\begin{array}{l}\text { The audit tool enabled all staff to observe hand } \\
\text { hygiene practices of other health care } \\
\text { professionals and, when hand hygiene is not } \\
\text { performed appropriately, to provide feedback. }\end{array}$ & $\begin{array}{l}\text { Other } \\
\text { professional } \\
\text { and support } \\
\text { staff. }\end{array}$ & $\begin{array}{l}\text { Registered } \\
\text { nurses, nursing } \\
\text { assistants and } \\
\text { unit } \\
\text { coordinators }\end{array}$ & Multiple & No \\
\hline Luke (69) & 2011 & $\begin{array}{l}\text { Quantitativ } \\
\text { e non- } \\
\text { randomised }\end{array}$ & 3 & USA & $\begin{array}{l}\text { Hospital: } \\
\text { occupational } \\
\text { health clinic }\end{array}$ & $\begin{array}{l}\text { To evaluate the effects of } \\
\text { immediate, personalized } \\
\text { performance feedback on }\end{array}$ & $\begin{array}{l}\text { Individual feedback on hand hygiene adherence } \\
\text { after observing patient contact. Feedback based } \\
\text { on a checklist of adherence with recommended } \\
\text { practices, both observed and opportunities }\end{array}$ & $\begin{array}{l}\text { Health-care } \\
\text { staff: nurse } \\
\text { practitioner, } \\
\text { physician } \\
\text { assistant, and }\end{array}$ & Unclear & $\begin{array}{l}\text { Multiple } \\
\text { (until mastery } \\
\text { criteria were } \\
\text { met). }\end{array}$ & No \\
\hline
\end{tabular}


This is the peer reviewed version of the following article: Mattick, K., Brennan, N. Briscoe, S. , Papoutsi, C. and Pearson, M. (2019), Optimising feedback for early career professionals: a scoping review and new framework. Med Educ, 53: 355-368, which has been published in final form at https://doi.org/10.1111/medu.13794. This article may be used for non-commercial purposes in accordance with Wiley Terms and Conditions for Use of Self-Archived Versions.

\begin{tabular}{|c|c|c|c|c|c|c|c|c|c|c|c|}
\hline & & & & & & $\begin{array}{l}\text { adherence with } \\
\text { hand hygiene. }\end{array}$ & $\begin{array}{l}\text { missed or incorrectly } \\
\text { performed. }\end{array}$ & $\begin{array}{l}\text { medical } \\
\text { assistant. }\end{array}$ & & & \\
\hline $\begin{array}{l}\text { Marra } \\
\text { (70) }\end{array}$ & 2008 & $\begin{array}{l}\text { Quantitativ } \\
\text { e non- } \\
\text { randomised }\end{array}$ & $\begin{array}{l}\text { (q7 } \\
\text { (questionn } \\
\text { aire } \\
\text { respondent } \\
\text { s) }\end{array}$ & Brazil & $\begin{array}{l}\text { Private hospital: } \\
\text { two adult step- } \\
\text { down units }\end{array}$ & $\begin{array}{l}\text { To evaluate hand hygiene } \\
\text { compliance following a } \\
\text { feedback intervention. }\end{array}$ & $\begin{array}{l}\text { Feedback of unit infection rates to Healthcare } \\
\text { Workers (HCWs) in intervention unit. Feedback } \\
\text { to individual HCWs showing dispenser use in } \\
\text { each patient room. Data added to } \\
\text { medical chart, to facilitate peer-comparison. }\end{array}$ & $\begin{array}{l}\text { Health care } \\
\text { workers, } \\
\text { especially } \\
\text { nurses }\end{array}$ & Nurse manager & Multiple & No \\
\hline $\begin{array}{l}\text { Mautone } \\
\text { (71) }\end{array}$ & 2006 & $\begin{array}{l}\text { Quantitativ } \\
\text { e non- } \\
\text { randomised }\end{array}$ & 1 & USA & $\begin{array}{l}\text { Public middle } \\
\text { school (grades } \\
6-8 \text { ) }\end{array}$ & $\begin{array}{l}\text { To illustrate a model of } \\
\text { behavioural consultation used } \\
\text { with a public } \\
\text { school teacher to improve } \\
\text { implementation of } \\
\text { instructional procedures in the } \\
\text { classroom. }\end{array}$ & $\begin{array}{l}\text { Classroom observation recording teacher and } \\
\text { student behaviours, followed by feedback that } \\
\text { reviewed session objectives, success in } \\
\text { implementing classroom behaviour } \\
\text { support plan. }\end{array}$ & $\begin{array}{l}\text { Sixth-grade } \\
\text { science } \\
\text { teacher }\end{array}$ & $\begin{array}{l}\text { Teacher } \\
\text { consultant } \\
\text { (author) }\end{array}$ & Multiple & No \\
\hline $\begin{array}{l}\text { McKenney } \\
\text { (72) }\end{array}$ & 2013 & $\begin{array}{l}\text { Quantitativ } \\
\text { e non- } \\
\text { randomised }\end{array}$ & 3 & USA & $\begin{array}{l}\text { Middle school: } \\
\text { general } \\
\text { education }\end{array}$ & $\begin{array}{l}\text { To explore the impact of } \\
\text { training and performance } \\
\text { feedback on integrity of } \\
\text { implementing functional } \\
\text { analyses procedures. }\end{array}$ & $\begin{array}{l}\text { Functional analyses procedures taught; teachers } \\
\text { observed during ongoing classroom instruction; } \\
\text { performance feedback given. }\end{array}$ & Teachers & Consultants & Multiple & No \\
\hline $\begin{array}{l}\text { McLellan } \\
\text { (28) }\end{array}$ & 2016 & $\begin{array}{l}\text { Mixed } \\
\text { methods }\end{array}$ & 14 & UK & Hospital & $\begin{array}{l}\text { To investigate whether and } \\
\text { how structured feedback } \\
\text { sessions can increase rates of } \\
\text { appropriate antimicrobial } \\
\text { prescribing by junior doctors. }\end{array}$ & $\begin{array}{l}\text { Individualized, written feedback } \\
\text { on appropriateness of trainees' prescribing of } \\
\text { antimicrobials, with peer comparison. Writing of } \\
\text { behaviour change plans by trainees. }\end{array}$ & $\begin{array}{l}\text { Junior } \\
\text { doctors }\end{array}$ & $\begin{array}{l}\text { Senior } \\
\text { pharmacist }\end{array}$ & Twice & Yes \\
\hline $\begin{array}{l}\text { Milanowsk } \\
\text { i (29) }\end{array}$ & 2005 & $\begin{array}{l}\text { Mixed } \\
\text { methods }\end{array}$ & $\begin{array}{l}144(50 \\
\text { split role } \\
\text { and } 94 \\
\text { combined } \\
\text { role) }\end{array}$ & USA & Schools & $\begin{array}{l}\text { To examine any differences } \\
\text { when splitting the feedback } \\
\text { role between different } \\
\text { feedback givers: either } \\
\text { summative evaluation and } \\
\text { formative coaching and } \\
\text { mentoring from a single } \\
\text { person; or the summative role } \\
\text { performed by one person and }\end{array}$ & $\begin{array}{l}\text { One group of new teachers received summative } \\
\text { evaluation and formative coaching and } \\
\text { mentoring from a single person, while for } \\
\text { another group the summative role was } \\
\text { performed by one person and the coach/mentor } \\
\text { role by another. }\end{array}$ & $\begin{array}{l}\text { Newly hired } \\
\text { teachers with } \\
\text { no prior } \\
\text { teaching } \\
\text { experience }\end{array}$ & $\begin{array}{l}\text { Peer mentors } \\
\text { and managers; } \\
\text { or combined } \\
\text { feedback from } \\
\text { peer evaluators. }\end{array}$ & Multiple & Yes \\
\hline
\end{tabular}


This is the peer reviewed version of the following article: Mattick, K., Brennan, N. Briscoe, S. , Papoutsi, C. and Pearson, M. (2019), Optimising feedback for early career professionals: a scoping review and new framework. Med Educ, 53: 355-368, which has been published in final form at https://doi.org/10.1111/medu.13794. This article may be used for non-commercial purposes in accordance with Wiley Terms and Conditions for Use of Self-Archived Versions.

\begin{tabular}{|c|c|c|c|c|c|c|c|c|c|c|c|}
\hline & & & & & & $\begin{array}{l}\text { the coach/mentor role by } \\
\text { another. }\end{array}$ & & & & & \\
\hline Minor (73) & 2014 & $\begin{array}{l}\text { Quantitativ } \\
\text { e non- } \\
\text { randomised }\end{array}$ & 3 & USA & $\begin{array}{l}\text { Schools: special } \\
\text { education }\end{array}$ & $\begin{array}{l}\text { To improve intervention } \\
\text { integrity of behaviour support } \\
\text { plan implementation. }\end{array}$ & $\begin{array}{l}\text { Classroom observation ( } 30 \text { minutes) of each } \\
\text { teacher-student dyad conducted. Data recorded } \\
\text { were analysed to provide an intervention } \\
\text { integrity percentage. Feedback included } \\
\text { corrective statements and praise, and } \\
\text { discussions about problem solving consultations. }\end{array}$ & $\begin{array}{l}\text { Special } \\
\text { education } \\
\text { teachers }\end{array}$ & $\begin{array}{l}\text { Teaching } \\
\text { consultant (first } \\
\text { author) }\end{array}$ & Multiple & No \\
\hline $\begin{array}{l}\text { Mouzakitis } \\
\text { (74) }\end{array}$ & 2015 & $\begin{array}{l}\text { Quantitativ } \\
\text { e non- } \\
\text { randomised }\end{array}$ & 4 & USA & $\begin{array}{l}\text { School: special } \\
\text { education }\end{array}$ & $\begin{array}{l}\text { To examine the use of self- } \\
\text { monitoring alone and with } \\
\text { performance to improve and } \\
\text { generalise treatment integrity } \\
\text { of individualized behaviour } \\
\text { intervention plans. }\end{array}$ & $\begin{array}{l}\text { Teachers were provided with each target } \\
\text { student's behaviour intervention plan, and self- } \\
\text { monitored their implementation. Feedback } \\
\text { provided until the teacher self-monitored with } \\
90 \% \text { accuracy then, performance feedback was } \\
\text { added to self-monitoring. }\end{array}$ & $\begin{array}{l}\text { Special } \\
\text { education } \\
\text { teachers }\end{array}$ & $\begin{array}{l}\text { Certified } \\
\text { behaviour } \\
\text { analyst (first } \\
\text { author) }\end{array}$ & Multiple & No \\
\hline Noell (75) & 1997 & $\begin{array}{l}\text { Quantitativ } \\
\text { e non- } \\
\text { randomised }\end{array}$ & 3 & USA & $\begin{array}{l}\text { Schools: } \\
\text { elementary } \\
\text { school }\end{array}$ & $\begin{array}{l}\text { To examine the treatment } \\
\text { integrity with which general } \\
\text { education teachers } \\
\text { implemented a reinforcement } \\
\text { based intervention designed to } \\
\text { improve the academic } \\
\text { performance of elementary } \\
\text { school students. }\end{array}$ & $\begin{array}{l}\text { Consultant shared student academic } \\
\text { performance data (outcome data) and teacher } \\
\text { intervention implementation data (process data) } \\
\text { and identified the specific treatment steps } \\
\text { missed the preceding day and how to improve } \\
\text { implementation that day. }\end{array}$ & Teachers & Consultant & Multiple & No \\
\hline $\begin{array}{l}\text { O'Horo } \\
\text { (76) }\end{array}$ & 2012 & $\begin{array}{l}\text { Quantitativ } \\
\text { e non- } \\
\text { randomised }\end{array}$ & $\begin{array}{l}\text { Unclear } \\
\text { (3184 } \\
\text { individual } \\
\text { patients } \\
\text { sign-outs) }\end{array}$ & USA & $\begin{array}{l}\text { Hospitals: one } \\
\text { general medical } \\
\text { and surgical; } \\
\text { and one tertiary } \\
\text { referral. }\end{array}$ & $\begin{array}{l}\text { To determine whether an } \\
\text { electronic handover system } \\
\text { and educational interventions } \\
\text { or a standard card-based } \\
\text { system would provide the most } \\
\text { complete, accurate and safe } \\
\text { handovers of patient care. }\end{array}$ & $\begin{array}{l}\text { One campus implemented the electronic } \\
\text { handover and educational interventions, } \\
\text { whereas the other continued to use a card- } \\
\text { based system. Residents rotated between the } \\
\text { campuses and systems were evaluated for } \\
\text { completeness, accuracy, and safety. }\end{array}$ & Residents & Auditors & One-off & No \\
\hline Pate (77) & 2012 & $\begin{array}{l}\text { Quantitativ } \\
\text { e non- } \\
\text { randomised } \\
: \text { before and } \\
\text { after }\end{array}$ & $\begin{array}{l}\text { Unclear } \\
(275 \\
\text { patient } \\
\text { chart } \\
\text { reviews) }\end{array}$ & USA & Hospital & $\begin{array}{l}\text { To audit an antimicrobial } \\
\text { stewardship program at a long- } \\
\text { term acute care hospital. }\end{array}$ & $\begin{array}{l}\text { Post-prescriptive chart audit with intervention } \\
\text { and feedback. Nonbinding recommendations } \\
\text { given. Infectious Disease consultation was } \\
\text { recommended when record review failed to }\end{array}$ & Medical staff & $\begin{array}{l}\text { Medical } \\
\text { director for } \\
\text { infection } \\
\text { control and }\end{array}$ & Multiple & No \\
\hline
\end{tabular}


This is the peer reviewed version of the following article: Mattick, K., Brennan, N. Briscoe, S. , Papoutsi, C. and Pearson, M. (2019), Optimising feedback for early career professionals: a scoping review and new framework. Med Educ, 53: 355-368, which has been published in final form at https://doi.org/10.1111/medu.13794. This article may be used for non-commercial purposes in accordance with Wiley Terms and Conditions for Use of Self-Archived Versions.

\begin{tabular}{|c|c|c|c|c|c|c|c|c|c|c|c|}
\hline & & & & & & & $\begin{array}{l}\text { reveal enough detail to optimise antimicrobial } \\
\text { therapy. }\end{array}$ & & $\begin{array}{l}\text { director of } \\
\text { pharmacy }\end{array}$ & & \\
\hline $\begin{array}{l}\text { Pessoa- } \\
\text { Silva (78) }\end{array}$ & 2007 & $\begin{array}{l}\text { Quantitativ } \\
\text { e non- } \\
\text { randomised } \\
: \text { before and } \\
\text { after }\end{array}$ & 101 & $\begin{array}{l}\text { Switzer } \\
\text { land }\end{array}$ & $\begin{array}{l}\text { Children's } \\
\text { hospital: } \\
\text { neonatal unit. }\end{array}$ & $\begin{array}{l}\text { To evaluate the impact of a } \\
\text { hand hygiene education } \\
\text { programme on individual } \\
\text { infection risk reduction among } \\
\text { neonates. }\end{array}$ & $\begin{array}{l}\text { The hand hygiene program was introduced; } \\
\text { compliance was assessed by observational } \\
\text { surveys; infection rates were assessed before, } \\
\text { during, and after. }\end{array}$ & $\begin{array}{l}\text { Physicians } \\
(\mathrm{n}=17) \text { and } \\
\text { nurses }(\mathrm{n}=84)\end{array}$ & Unclear & $\begin{array}{l}\text { Twice after } \\
\text { the } \\
\text { intervention }\end{array}$ & No \\
\hline $\begin{array}{l}\text { Proude } \\
\text { (79) }\end{array}$ & 2008 & $\begin{array}{l}\text { Quantitativ } \\
\text { e non- } \\
\text { randomised }\end{array}$ & 65 & $\begin{array}{l}\text { Austral } \\
\text { ia }\end{array}$ & $\begin{array}{l}\text { Hospitals: one } \\
\text { feedback, one } \\
\text { control }\end{array}$ & $\begin{array}{l}\text { To determine whether } \\
\text { individual feedback on current } \\
\text { clinical practice improved } \\
\text { assessment and management } \\
\text { of risky alcohol use in } \\
\text { inpatients; and the indirect } \\
\text { effects on recording of tobacco } \\
\text { smoking and prescription of } \\
\text { nicotine replacement therapy. }\end{array}$ & $\begin{array}{l}\text { Medical records of patients admitted by junior } \\
\text { medical officers were examined for recording of } \\
\text { alcohol-related information. The intervention } \\
\text { involved printed individual feedback on their } \\
\text { own and their group's performance, while the } \\
\text { control site just attended a presentation of their } \\
\text { group feedback. }\end{array}$ & $\begin{array}{l}\text { Junior } \\
\text { doctors (first } \\
2 \text { years of } \\
\text { clinical } \\
\text { practice). }\end{array}$ & $\begin{array}{l}\text { Unclear } \\
\text { (individual); } \\
\text { staff specialist } \\
\text { in Addiction } \\
\text { Medicine } \\
\text { (group). }\end{array}$ & Multiple & No \\
\hline $\begin{array}{l}\text { Rathel (80) } \\
\text { (thesis) }\end{array}$ & 2009 & Same study a & Rathel 2014 & & & & & & & & No \\
\hline $\begin{array}{l}\text { Rathel (81) } \\
\text { (publicatio } \\
\text { n) }\end{array}$ & 2014 & $\begin{array}{l}\text { Quantitativ } \\
\text { e non- } \\
\text { randomised } \\
\text { : before and } \\
\text { after }\end{array}$ & 4 & USA & $\begin{array}{l}\text { School: special } \\
\text { education } \\
\text { classrooms. }\end{array}$ & $\begin{array}{l}\text { To evaluate the impact of e- } \\
\text { mailed specific performance } \\
\text { feedback on teachers ratio of } \\
\text { positive-to-negative } \\
\text { communication behaviours; } \\
\text { and behaviour-specific praise; } \\
\text { and to evaluate if this leads to } \\
\text { increased students task } \\
\text { engagement. }\end{array}$ & $\begin{array}{l}\text { Classroom observations were conducted at the } \\
\text { same time each day using a method to record } \\
\text { communication behaviours. The intervention } \\
\text { consisted of an initial } 30 \text { min meeting with each } \\
\text { teacher and a follow up e-mail containing } \\
\text { specific performance feedback. }\end{array}$ & $\begin{array}{l}\text { Induction } \\
\text { year teachers }\end{array}$ & $\begin{array}{l}\text { First } \\
\text { author/researc } \\
\text { her }\end{array}$ & Multiple & No \\
\hline $\begin{array}{l}\text { Redwood } \\
\text { (27) }\end{array}$ & 2013 & $\begin{array}{l}\text { Mixed } \\
\text { methods }\end{array}$ & 42 & UK & $\begin{array}{l}\text { Teaching } \\
\text { hospital }\end{array}$ & $\begin{array}{l}\text { To establish whether a Junior } \\
\text { Doctor Dashboard providing } \\
\text { feedback on prescription } \\
\text { warning information and } \\
\text { laboratory alerting acceptance } \\
\text { rates was effective in changing } \\
\text { junior doctors' behaviour. }\end{array}$ & $\begin{array}{l}\text { The intervention group were e-mailed a link to a } \\
\text { personal dashboard every week for } 4 \text { months. } \\
\text { Outcome measures were differences between } \\
\text { groups in responses to prescribing warnings (of } \\
\text { two severities) and laboratory alerting (of two } \\
\text { severities) in the months before and during the } \\
\text { intervention. }\end{array}$ & $\begin{array}{l}\text { Junior } \\
\text { doctors } \\
\text { (below } \\
\text { specialty } \\
\text { trainee level } \\
\text { 3 grade). }\end{array}$ & $\begin{array}{l}\text { Automated } \\
\text { feedback }\end{array}$ & Multiple & Yes \\
\hline
\end{tabular}


This is the peer reviewed version of the following article: Mattick, K., Brennan, N. Briscoe, S. , Papoutsi, C. and Pearson, M. (2019), Optimising feedback for early career professionals: a scoping review and new framework. Med Educ, 53: 355-368, which has been published in final form at https://doi.org/10.1111/medu.13794. This article may be used for non-commercial purposes in accordance with Wiley Terms and Conditions for Use of Self-Archived Versions.

\begin{tabular}{|c|c|c|c|c|c|c|c|c|c|c|c|}
\hline $\begin{array}{l}\text { Render } \\
(82)\end{array}$ & 2011 & $\begin{array}{l}\text { Quantitativ } \\
\text { e non- } \\
\text { randomised } \\
\text { : before and } \\
\text { after }\end{array}$ & $\begin{array}{l}\text { Unclear } \\
(174 \\
\text { intensive } \\
\text { care units) }\end{array}$ & USA & $\begin{array}{l}\text { Hospitals: } 174 \\
\text { intensive care } \\
\text { units in } 123 \\
\text { hospitals. }\end{array}$ & $\begin{array}{l}\text { To describe implementation of } \\
\text { a practice bundle to reduce } \\
\text { central-line associated } \\
\text { bloodstream infections using } \\
\text { infrastructure elements } \\
\text { focused on building leadership } \\
\text { support, measurement, shared } \\
\text { learning, mentoring and teams } \\
\text { to move practices. }\end{array}$ & $\begin{array}{l}\text { The practice bundle included multiple strategies } \\
\text { to reduce central line-associated bloodstream } \\
\text { infections and support for the bundle included } \\
\text { recruiting leadership, benchmarked feedback, } \\
\text { learning tools and selective mentoring. }\end{array}$ & $\begin{array}{l}\text { Frontline } \\
\text { nurses and } \\
\text { doctors }\end{array}$ & Unclear & Unclear & No \\
\hline $\begin{array}{l}\text { Rodriguez } \\
\text { (83) }\end{array}$ & 2009 & $\begin{array}{l}\text { Quantitativ } \\
\text { e non- } \\
\text { randomised } \\
\text { : before and } \\
\text { after }\end{array}$ & 3 & USA & School & $\begin{array}{l}\text { To reduce problem behaviours } \\
\text { for young children at risk for } \\
\text { school failure. }\end{array}$ & $\begin{array}{l}\text { Implemented First Step to Success, a } \\
\text { "manualized" intervention. Explored the role of } \\
\text { performance feedback from FSS coaches on the } \\
\text { fidelity of implementation. Student behaviour } \\
\text { and teacher implementation fidelity were } \\
\text { assessed after coaching and compared to } \\
\text { baseline. }\end{array}$ & Teachers & $\begin{array}{l}\text { 'First Step to } \\
\text { Success' } \\
\text { coaches }\end{array}$ & Multiple & No \\
\hline $\begin{array}{l}\text { Sanetti } \\
(84)\end{array}$ & 2014 & $\begin{array}{l}\text { Quantitativ } \\
\text { e non- } \\
\text { randomised } \\
\text { : before and } \\
\text { after }\end{array}$ & 3 & USA & $\begin{array}{l}\text { Education: } \\
\text { suburban public } \\
\text { middle school }\end{array}$ & $\begin{array}{l}\text { To provide an exploratory } \\
\text { evaluation of the effectiveness } \\
\text { and feasibility of performance } \\
\text { feedback from a school-based } \\
\text { consultant to teachers } \\
\text { implementing a class wide } \\
\text { behavioural intervention. }\end{array}$ & $\begin{array}{l}\text { The intervention in this study consisted of two } \\
\text { components: student self-monitoring using DBR- } \\
\text { SIS (i.e. skill building) and interdependent group } \\
\text { contingency management i.e. positive } \\
\text { reinforcement. }\end{array}$ & $\begin{array}{l}\text { Special } \\
\text { education } \\
\text { teacher and } 2 \\
\text { eight-grade } \\
\text { teachers }\end{array}$ & $\begin{array}{l}\text { School-based } \\
\text { consultant }\end{array}$ & $\begin{array}{l}\text { Multiple } \\
\text { times }\end{array}$ & No \\
\hline $\begin{array}{l}\text { Schwartzb } \\
\text { erg (85) }\end{array}$ & 2006 & $\begin{array}{l}\text { Quantitativ } \\
\text { e non- } \\
\text { randomised }\end{array}$ & Unclear & Israel & $\begin{array}{l}\text { Hospital: acute } \\
\text { secondary care }\end{array}$ & $\begin{array}{l}\text { To evaluate a } 3 \text { stage model for } \\
\text { changing physicians prescribing } \\
\text { habits. }\end{array}$ & $\begin{array}{l}\text { A } 3 \text { stage model for changing physicians } \\
\text { prescribing habits was implemented: } 1 \text { ) } \\
\text { management actions influencing all staff e.g. } \\
\text { creation of guidelines, 2) reorganisation of } \\
\text { restricted antibiotics prescription authorisation } \\
\text { system, 3) new role for clinical pharmacist } \\
\text { feeding back to attending doctor using academic } \\
\text { detailing strategies and evidence-based } \\
\text { pharmacotherapy criteria. }\end{array}$ & Physicians & $\begin{array}{l}\text { Clinical } \\
\text { pharmacist }\end{array}$ & Multiple & No \\
\hline $\begin{array}{l}\text { Suhrheinri } \\
\text { ch (86) }\end{array}$ & 2010 & $\begin{array}{l}\text { Quantitativ } \\
\text { e non- } \\
\text { randomised }\end{array}$ & 9 & USA & $\begin{array}{l}\text { Education: } \\
\text { three training } \\
\text { groups }\end{array}$ & $\begin{array}{l}\text { To assess the benefits of using } \\
\text { the Train The Teacher model to } \\
\text { disseminate Pivotal Response } \\
\text { Training, an evidence-based }\end{array}$ & $\begin{array}{l}\text { Trainers and teachers were taught to use Pivotal } \\
\text { Response Training. Trainers observed } \\
\text { teacher/student interactions and provided } \\
\text { feedback. Trainer and teacher ability to }\end{array}$ & $\begin{array}{l}\text { Special } \\
\text { education } \\
\text { teachers }\end{array}$ & $\begin{array}{l}\text { Trainers (school } \\
\text { members) }\end{array}$ & Multiple & No \\
\hline
\end{tabular}


This is the peer reviewed version of the following article: Mattick, K., Brennan, N. Briscoe, S. , Papoutsi, C. and Pearson, M. (2019), Optimising feedback for early career professionals: a scoping review and new framework. Med Educ, 53: 355-368, which has been published in final form at https://doi.org/10.1111/medu.13794. This article may be used for non-commercial purposes in accordance with Wiley Terms and Conditions for Use of Self-Archived Versions.

\begin{tabular}{|c|c|c|c|c|c|c|c|c|c|c|c|}
\hline & & $\begin{array}{l}\text { : before and } \\
\text { after }\end{array}$ & & & & $\begin{array}{l}\text { practice for educating children } \\
\text { with autism, to school settings. }\end{array}$ & $\begin{array}{l}\text { implement PRT, trainer ability to assess PRT and } \\
\text { provide feedback, and student language and } \\
\text { behavioural changes were assessed before and } \\
\text { after training }\end{array}$ & & & & \\
\hline $\begin{array}{l}\text { Sullivan } \\
\text { (87) }\end{array}$ & 2013 & $\begin{array}{l}\text { Quantitativ } \\
\text { e non- } \\
\text { randomised } \\
\text { : before and } \\
\text { after }\end{array}$ & Unclear & USA & $\begin{array}{l}\text { Hospital: } \\
\text { neonatal } \\
\text { Intensive Care } \\
\text { Unit }\end{array}$ & $\begin{array}{l}\text { To report the development of a } \\
\text { prescribing error feedback } \\
\text { programme, and its impact on } \\
\text { narcotic prescribing errors. }\end{array}$ & $\begin{array}{l}\text { A front- line multidisciplinary team doing } \\
\text { multiple Plan Do Study Act cycles developed a } \\
\text { system to communicate prescribing errors } \\
\text { directly to providers every two weeks in the } \\
\text { NICU. }\end{array}$ & $\begin{array}{l}\text { Fellows, } \\
\text { nurse } \\
\text { practitioners, } \\
\text { physician } \\
\text { assistants }\end{array}$ & $\begin{array}{l}\text { Multidisciplinar } \\
\text { y team via e- } \\
\text { mail }\end{array}$ & $\begin{array}{l}\text { Multiple } \\
\text { times }\end{array}$ & No \\
\hline Tang (88) & 2007 & Qualitative & 21 & China & Education & $\begin{array}{l}\text { To evaluate feedback } \\
\text { communicated in post- } \\
\text { observation conferences in } \\
\text { teaching practice supervision. }\end{array}$ & $\begin{array}{l}32 \text { post-observation conferences between } 21 \\
\text { pairs of supervisors and participants of in-service } \\
\text { teacher education programmes, and interviews } \\
\text { with supervisors and participants were analysed. }\end{array}$ & $\begin{array}{l}\text { In-service } \\
\text { teacher } \\
\text { education } \\
\text { programme } \\
\text { participants }\end{array}$ & Supervisors & $\begin{array}{l}\text { Multiple } \\
\text { times }\end{array}$ & Yes \\
\hline Witt (89) & 1997 & $\begin{array}{l}\text { Quantitativ } \\
\text { e non- } \\
\text { randomised } \\
: \text { before and } \\
\text { after }\end{array}$ & 4 & USA & $\begin{array}{l}\text { Education: } \\
\text { elementary } \\
\text { school }\end{array}$ & $\begin{array}{l}\text { To examine the impact of } \\
\text { performance feedback on the } \\
\text { implementation of a } \\
\text { reinforcement-based } \\
\text { treatment by general } \\
\text { education teachers. }\end{array}$ & $\begin{array}{l}\text { The study examined the integrity with which } 4 \\
\text { general education teachers implemented an } \\
\text { intervention designed to improve the academic } \\
\text { performance of elementary school students. }\end{array}$ & Teacher & Consultant & $\begin{array}{l}\text { multiple } \\
\text { times }\end{array}$ & No \\
\hline Zhu (90) & 2015 & $\begin{array}{l}\text { Quantitativ } \\
\text { e non- } \\
\text { randomised }\end{array}$ & 4 & USA & $\begin{array}{l}\text { Education: } 4 \\
\text { public } \\
\text { elementary } \\
\text { schools }\end{array}$ & $\begin{array}{l}\text { To examine the impact of } \\
\text { performance feedback on } \\
\text { treatment integrity and } \\
\text { student outcomes for a } \\
\text { standard protocol, class-wide } \\
\text { reading intervention for grades } \\
2 \text { to } 6 \text {. }\end{array}$ & $\begin{array}{l}\text { Consultant observed lessons and measured } \\
\text { integrity twice a week. Consultant met teacher } \\
\text { to provide feedback on previous session, suggest } \\
\text { strengths / improvements and provide } \\
\text { corrective feedback on missed items } \\
\text { (behaviours). Teacher asked to remind class } \\
\text { about missed items. }\end{array}$ & $\begin{array}{l}\text { Teachers } \\
\text { (grade 2-5 } \\
\text { general } \\
\text { education } \\
\text { teachers) }\end{array}$ & Consultants & Multiple & No \\
\hline
\end{tabular}


This is the peer reviewed version of the following article: Mattick, K., Brennan, N. Briscoe, S. , Papoutsi, C. and Pearson, M. (2019), Optimising feedback for early career professionals: a scoping review and new framework. Med Educ, 53: 355-368, which has been published in final form at https://doi.org/10.1111/medu.13794. This article may be used for non-commercial purposes in accordance with Wiley Terms and Conditions for Use of Self-Archived Versions.

\section{Table 4: Literature reviews included in our study.}

\begin{tabular}{|c|c|c|c|c|c|c|}
\hline 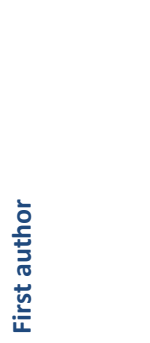 & ֻ & 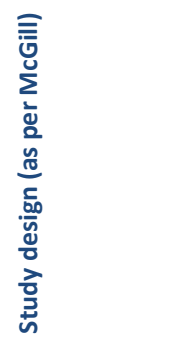 & 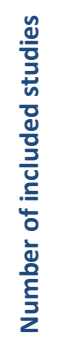 & 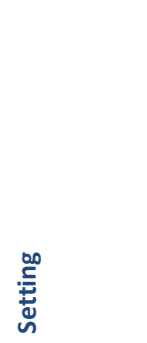 & $\frac{E}{\varepsilon}$ & 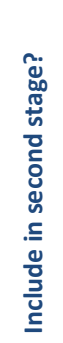 \\
\hline Balas (91) & 1996 & $\begin{array}{l}\text { Systematic } \\
\text { review / meta- } \\
\text { analysis }\end{array}$ & 12 & Healthcare & To assess the clinical effect of peer-comparison feedback intervention (profiles) in changing practice patterns. & No \\
\hline De Vos (92) & 2009 & $\begin{array}{l}\text { Systematic } \\
\text { review }\end{array}$ & 21 & Hospital & To explore effectiveness of strategies for implementing quality indicators in improving the quality of hospital care. & No \\
\hline Dulko (93) & 2007 & $\begin{array}{l}\text { Systematic } \\
\text { review }\end{array}$ & 16 & Hospital & $\begin{array}{l}\text { To evaluate available research evidence regarding the effectiveness of audit and feedback as a guideline implementation strategy within } \\
\text { nursing. }\end{array}$ & Yes \\
\hline $\begin{array}{l}\text { Hysong } \\
\text { (18) }\end{array}$ & 2009 & Meta-analysis & 19 & Healthcare & $\begin{array}{l}\text { To test whether Feedback Intervention Theory explains variability in health care Audit and Feedback research, by examining the } \\
\text { relationship between A\&F and clinical practice guideline adherence. }\end{array}$ & Yes \\
\hline Ista (94) & 2013 & $\begin{array}{l}\text { Systematic } \\
\text { review }\end{array}$ & 23 & Hospitals & To review comparative evidence for implementation strategies to improve nurses' adherence to pain assessment recommendations. & No \\
\hline Ivers (3) & 2012 & $\begin{array}{l}\text { Systematic } \\
\text { review / meta- } \\
\text { analysis } \\
\text { (Cochrane) }\end{array}$ & 140 & $\begin{array}{l}\text { Healthcare } \\
\text { settings }\end{array}$ & $\begin{array}{l}\text { To assess the effects of audit and feedback on the practice of healthcare professionals and patient outcomes and to examine factors } \\
\text { that may explain variation in the effectiveness of audit and feedback. }\end{array}$ & Yes \\
\hline Ivers (4) & 2014 & $\begin{array}{l}\text { Systematic } \\
\text { Review }\end{array}$ & 140 & Healthcare & $\begin{array}{l}\text { To explore the effect of audit and feedback on professional practice over time and explore how optimize the effectiveness of audit and } \\
\text { feedback. }\end{array}$ & Yes \\
\hline
\end{tabular}


This is the peer reviewed version of the following article: Mattick, K., Brennan, N. , Briscoe, S. , Papoutsi, C. and Pearson, M. (2019), Optimising feedback for early career professionals: a scoping review and new framework. Med Educ, 53: 355-368, which has been published in final form at https://doi.org/10.1111/medu.13794. This article may be used for non-commercial purposes in accordance with Wiley Terms and Conditions for Use of Self-Archived Versions.

\begin{tabular}{|c|c|c|c|c|c|c|}
\hline $\begin{array}{l}\text { Jamtvedt } \\
\text { (36) }\end{array}$ & 2003 & $\begin{array}{l}\text { Systematic } \\
\text { review } \\
\text { (Cochrane) }\end{array}$ & 85 & Healthcare & To assess the effects of audit and feedback on the practice of healthcare professionals and patient outcomes & No \\
\hline $\begin{array}{l}\text { Jamtvedt } \\
(25)\end{array}$ & 2006 & $\begin{array}{l}\text { Systematic } \\
\text { review }\end{array}$ & 118 & Healthcare & An update of a Cochrane review to assess the effects of audit and feedback. & No \\
\hline Kluger (5) & 1996 & $\begin{array}{l}\text { Historical } \\
\text { review and } \\
\text { meta-analysis }\end{array}$ & 131 & Various/unclear & $\begin{array}{l}\text { To provide a historical review; to conduct a meta-analysis to demonstrate the large variability Feedback Intervention effects on } \\
\text { performance; and to account for some of the feedback interventions' variability through a preliminary theory. }\end{array}$ & Yes \\
\hline Lavoie (37) & 2009 & $\begin{array}{l}\text { Systematic } \\
\text { review }\end{array}$ & 7 & $\begin{array}{l}\text { Hospital: } \\
\text { Emergency } \\
\text { medicine }\end{array}$ & To determine what is currently known about outcome feedback in emergency medicine, including its incidence, impact and modifiers & No \\
\hline $\begin{array}{l}\text { Mugford } \\
\text { (38) }\end{array}$ & 1991 & $\begin{array}{l}\text { Systematic } \\
\text { review }\end{array}$ & 36 & Healthcare & To establish what is known about the role of feedback of statistical information in changing clinical practice & No \\
\hline $\begin{array}{l}\text { Naikoba } \\
(95)\end{array}$ & 2001 & $\begin{array}{l}\text { Systematic } \\
\text { review }\end{array}$ & 21 & Healthcare & $\begin{array}{l}\text { To summarise and assess effectiveness of interventions to increase compliance with handwashing in healthcare workers, as a hospital } \\
\text { infection control measure. }\end{array}$ & No \\
\hline Noell (96) & 2014 & Meta-analysis & 29 & Schools & To examine procedures, including performance feedback alone or in combination, to improve treatment plan implementation. & No \\
\hline Rogers (19) & 2015 & $\begin{array}{l}\text { Systematic } \\
\text { review }\end{array}$ & 24 & $\begin{array}{l}\text { Hospital: } \\
\text { Emergency } \\
\text { medicine }\end{array}$ & To assess the effect of audit and feedback on emergency physician performance and to identify features critical to success. & Yes \\
\hline $\begin{array}{l}\text { Saedon } \\
\text { (97) }\end{array}$ & 2012 & $\begin{array}{l}\text { Systematic } \\
\text { Review }\end{array}$ & 15 & $\begin{array}{l}\text { Healthcare: } \\
\text { Postgraduate } \\
\text { medical training }\end{array}$ & To elucidate the impact of feedback on the effectiveness of workplace-based assessments in postgraduate medical training & No \\
\hline $\begin{array}{l}\text { Shojania } \\
(39)\end{array}$ & 2010 & $\begin{array}{l}\text { Systematic } \\
\text { review }\end{array}$ & 28 & Healthcare & $\begin{array}{l}\text { To quantify the expected magnitude of improvements in processes of care from computer reminders delivered to clinicians during their } \\
\text { routine activities. }\end{array}$ & No \\
\hline $\begin{array}{l}\text { Solomon } \\
(98)\end{array}$ & 2012 & Meta-analysis & 36 & $\begin{array}{l}\text { Education: } \\
\text { Classroom }\end{array}$ & $\begin{array}{l}\text { To review applications of performance feedback in school settings and catalogue the various effects of different characteristics of } \\
\text { performance feedback. }\end{array}$ & No \\
\hline $\begin{array}{l}\text { van de } \\
\text { Ridder (13) }\end{array}$ & 2015 & Meta-review & 46 & $\begin{array}{l}\text { Medicine: } \\
\text { medical training }\end{array}$ & $\begin{array}{l}\text { To explore which variables in the feedback process influence either the first or subsequent phases in this process or a second } \\
\text { performance of the same task }\end{array}$ & No \\
\hline
\end{tabular}


This is the peer reviewed version of the following article: Mattick, K. , Brennan, N. , Briscoe, S. , Papoutsi, C. and Pearson, M. (2019), Optimising feedback for early career professionals: a scoping review and new framework. Med Educ, 53: 355-368, which has been published in final form at https://doi.org/10.1111/medu.13794. This article may be used for non-commercial purposes in accordance with Wiley Terms and Conditions for Use of Self-Archived Versions.

\begin{tabular}{|c|c|c|c|c|c|c|}
\hline $\begin{array}{l}\text { Veloski } \\
\text { (99) }\end{array}$ & 2006 & $\begin{array}{l}\text { Systematic } \\
\text { review }\end{array}$ & 41 & Healthcare & To summarise evidence related to the impact of assessment and feedback on physicians clinical performance & No \\
\hline
\end{tabular}


Table 5: Framework describing key components of Feedback Interventions (Fls) and the sub-components of Audit, Feedback, Goal-Setting process,

together with a summary of evidence outlining 'good practice' from the included papers. In the column headed 'Strength of the Evidence', we have formed a judgment about the strength of the evidence found via this scoping review. We use a star system to show our summary judgment (1 star: based on theory but not disproved by data; 2 star: based on limited empirical data; 3 star: based on a high quality evidence synthesis; 4 star: based on multiple high quality evidence syntheses; 5 star: Unlikely to be 'disproved'). Note that these star system descriptors must be considered indicative only, however, since sometimes there was a high quality evidence synthesis available but only a small part of it focussed on this specific aspect, and so we are only drawing on arguments that may not be as strongly supported with data.

\begin{tabular}{|c|c|c|c|c|}
\hline Category & Sub-category & Example/level & Summary of evidence for designers of Feedback Interventions (FI) for Early Career Professionals (ECPs) & $\begin{array}{l}\text { Strength } \\
\text { of the } \\
\text { evidence }\end{array}$ \\
\hline \multirow[t]{5}{*}{ 1. Audit } & $\begin{array}{l}1.1 \text { Complexity of } \\
\text { task chosen }\end{array}$ & $\begin{array}{l}\text { Simple, } \\
\text { complicated, } \\
\text { complex }\end{array}$ & $\begin{array}{l}\text { - Professional practice is characterised by complex tasks, such as those involving judgment or novelty. } \\
\text { Published studies rarely define the type of task or behaviour targeted by feedback but the impact is likely to vary by task: for } \\
\text { example, the impact of a Feedback Intervention (FI) is probably smaller for more complex tasks (5). }\end{array}$ & $*$ \\
\hline & $\begin{array}{l}\text { 1.2 Type of task } \\
\text { chosen }\end{array}$ & $\begin{array}{l}\text { Memory task, } \\
\text { physical task }\end{array}$ & $\begin{array}{l}\text { - Many included studies used compliance with a policy as their outcome measure. } \\
\text { - For ECPs there may be a greater focus on compliance than autonomous decision making but, as expertise develops, judging } \\
\text { when it is appropriate to deviate from a policy may be necessary within professional practice (27). }\end{array}$ & * \\
\hline & $\begin{array}{l}1.3 \text { Nature of data } \\
\text { to be collected }\end{array}$ & $\begin{array}{l}\text { Quantitative, } \\
\text { qualitative, mixed }\end{array}$ & $\begin{array}{l}\text { - Different types of data may be selected when providing feedback for different purposes but the rationale for the choice is } \\
\text { rarely articulated (29). } \\
\text { - The perceived focus of the feedback exercise is influenced by the choice of feedback data (88) but recipient perceptions are } \\
\text { sometimes hard to predict (27) and may depend on context, for example whether performance data may be perceived as } \\
\text { linked to assessment judgments or probation (63). } \\
\text { Quantitative data seem to pre-empt more 'summative' conversations about performance, whereas qualitative data may set } \\
\text { up more developmental conversations. } \\
\text { - } \quad \text { Recipients may require support to interpret and respond to quantitative data in particular (29). } \\
\text { Feedback criteria can be embedded within a learning process, for example by setting expectations about performance at the } \\
\text { outset (33). }\end{array}$ & * \\
\hline & $\begin{array}{l}\text { 1.4 Metric } \\
\text { importance to the } \\
\text { intended } \\
\text { recipient }\end{array}$ & $\begin{array}{l}\text { High, medium, } \\
\text { low }\end{array}$ & $\begin{array}{l}\text { - Feedback metrics that are aligned to the priorities of the recipient and/or the organisation are likely to have greater impact, } \\
\text { as is feedback that is solicited by the recipient (33). } \\
\text { Recipients tend to value performance data that is directly relevant to their work, for example on specific practice scenarios } \\
(27,33,88) \text {. } \\
\text { It is important to consider whether 'more' or 'less' of the targeted behaviour is always desirable or whether an optimal level } \\
\text { may apply (63). }\end{array}$ & * \\
\hline & $\begin{array}{l}\text { 1.5 Data } \\
\text { credibility }\end{array}$ & $\begin{array}{l}\text { High, medium, } \\
\text { low }\end{array}$ & $\begin{array}{l}\text { External guidelines or standards were often used as credible sources of practice standards }(31,60,63) \text { and sometimes data } \\
\text { were signed off or sent by a senior practitioner or group/committee to lend credibility. } \\
\text { When credibility of feedback data is open to challenge (e.g. inconsistent messages, second hand sources, lacking awareness } \\
\text { of the working context), the feedback process could be undermined }(29,30,33) \text {. }\end{array}$ & ** \\
\hline
\end{tabular}


This is the peer reviewed version of the following article: Mattick, K., Brennan, N. Briscoe, S. , Papoutsi, C. and Pearson, M. (2019), Optimising feedback for early career professionals: a scoping review and new framework. Med Educ, 53: 355-368, which has been published in final form at https://doi.org/10.1111/medu.13794. This article may be used for non-commercial purposes in accordance with Wiley Terms and Conditions for Use of Self-Archived Versions.

\begin{tabular}{|c|c|c|c|c|}
\hline & & & $\begin{array}{l}\text { - For ECPs who often work under supervision, performance data are sometimes not a fair reflection of ECP's own clinical } \\
\text { practice, since they may be enacting the wishes of their seniors (27). } \\
\text { - Where teamwork or shift work is common, it may be hard to attribute particular decisions/outcomes to individuals (60). } \\
\text { - Feedback messages may be undermined by contextual cues or other feedback sources (5). }\end{array}$ & \\
\hline & $\begin{array}{l}\text { 1.6 Baseline } \\
\text { performance }\end{array}$ & $\begin{array}{l}\text { Very low, low, } \\
\text { average, high, } \\
\text { very high }\end{array}$ & $\begin{array}{l}\text { - If the feedback 'sign' is extremely positive or negative (i.e. performance is very high or low), arousal is likely to be greater } \\
\text { than an average or absent feedback sign (5). } \\
\text { - Feedback is most effective when baseline performance is low }(3,4,19) \text { or moderate (19), which is likely for ECPs. } \\
\text { - However, if baseline performance is very low, then rapid improvement is needed to sustain engagement with the task; and if } \\
\text { baseline performance is already high or very high, it is likely that effort will be maintained or reduced (5). }\end{array}$ & $* * *$ \\
\hline \multirow[t]{5}{*}{$\begin{array}{l}2 . \\
\text { Feedback } \\
\text { interventi } \\
\text { on }\end{array}$} & $\begin{array}{l}2.1 \text { Feedback } \\
\text { format }\end{array}$ & $\begin{array}{l}\text { Electronic, } \\
\text { verbally, written, } \\
\text { graphical. } \\
\text { Public, } \\
\text { confidential }\end{array}$ & $\begin{array}{l}\text { Effectiveness of feedback seems to depend on how it is provided (3). } \\
\text { Written feedback appears more effective than verbal or graphical delivery (18), although a combination may be beneficial } \\
\text { (3). } \\
\text { This may be because written or electronic sharing allows attention to focus on the task, whereas face-to-face feedback may } \\
\text { trigger meta-task processes and affective reactions }(5,18) \text {. } \\
\text { Public feedback and peer comparisons are less likely to be effective because they may direct attention to meta-task } \\
\text { processes }(5,27) \text {, although this requires further research (3). }\end{array}$ & $* * *$ \\
\hline & $\begin{array}{l}2.2 \text { Comparison } \\
\text { to other data }\end{array}$ & $\begin{array}{l}\text { To peers, past } \\
\text { performance, } \\
\text { explicit } \\
\text { standard(s) }\end{array}$ & $\begin{array}{l}\text { Individuals who are performing better than their peers may not strive to improve further or may even decrease effort (5, } \\
\text { 27). } \\
\text { Comparison to past performance (feedback on progress over time) is likely to direct attention to the task and therefore } \\
\text { augment performance (5). } \\
\text { If there is no clear standard against which to compare feedback (e.g. a new task), then there may be little motivation to } \\
\text { change, unless goals are provided (5). }\end{array}$ & $* *$ \\
\hline & $\begin{array}{l}2.3 \text { Judgment } \\
\text { made on data }\end{array}$ & $\begin{array}{l}\text { None, praise, } \\
\text { displeasure }\end{array}$ & $\begin{array}{l}\text { - With cognitively demanding tasks, which are common in professional practice, both praise and discouragement may } \\
\text { increase attention to meta-task processes and therefore lessen impact (5). }\end{array}$ & * \\
\hline & $\begin{array}{l}\text { 2.4 Content of } \\
\text { feedback }\end{array}$ & Specific, generic & $\begin{array}{l}\text { - A number of authors advocate specific, individualised feedback }(18,33) \text { suggesting a belief that this is likely to be effective. } \\
\text { However, feedback that is too specific may direct attention below the level necessary for optimal performance }(5) \text {. } \\
\text { According to FIT, feedback on group performance should augment performance because it diverts attention away from the } \\
\text { self }(5) \text { but it may lack meaning for an individual. }\end{array}$ & * \\
\hline & $\begin{array}{l}2.5 \text { Likelihood of } \\
\text { feedback to be } \\
\text { perceived as a } \\
\text { threat }\end{array}$ & $\begin{array}{l}\text { High, medium, } \\
\text { low }\end{array}$ & $\begin{array}{l}\text { - Feedback, particularly negative feedback, may be perceived as a threat to self-esteem or to external rewards/punishments } \\
\text { (5). } \\
\text { - Study participants acknowledged concern about how data would be used e.g. for clinical accountability, or to enforce } \\
\text { disciplinary action (27). } \\
\text { - Feedback that is non-punitive, non-evaluative and non-threatening }(18,33,93) \text { will reduce the perception of threat. } \\
\text { - The benefits of using 'authoritative' sources to increase the perceived credibility of feedback information (30), must be } \\
\text { weighed up against the risks of this making the feedback seem more threatening. } \\
\text { No benefits were observed when formative and summative elements of feedback were separated, in an attempt to } \\
\text { encourage honesty and openness about weaknesses and the setting of challenging goals (29). }\end{array}$ & $* *$ \\
\hline
\end{tabular}


This is the peer reviewed version of the following article: Mattick, K., Brennan, N. Briscoe, S. , Papoutsi, C. and Pearson, M. (2019), Optimising feedback for early career professionals: a scoping review and new framework. Med Educ, 53: 355-368, which has been published in final form at https://doi.org/10.1111/medu.13794. This article may be used for non-commercial purposes in accordance with Wiley Terms and Conditions for Use of Self-Archived Versions.

\begin{tabular}{|c|c|c|c|c|}
\hline & $\begin{array}{l}2.6 \text { Correct } \\
\text { solution } \\
\text { information }\end{array}$ & Present, absent & $\begin{array}{l}\text { - Providing a 'correct solution' as part of feedback is thought to increase its likely impact }(5,18) \text { by focussing attention on } \\
\text { target behaviour. } \\
\text { However, 'correct solutions' may be challenging to identify within professional practice, where complex judgments in a } \\
\text { messy practice context are common. }\end{array}$ & $* * *$ \\
\hline & $\begin{array}{l}2.7 \text { Timing and } \\
\text { frequency of } \\
\text { feedback }\end{array}$ & $\begin{array}{l}\text { One off, multiple } \\
\text { times } \\
\text { Within a week, } \\
\text { after more than a } \\
\text { week }\end{array}$ & $\begin{array}{l}\text { - Feedback is thought to be most effective when presented more than once }(3,4,18,33,56) \text {. } \\
\text { - More feedback, provided closer to the performance event, was felt to be beneficial }(28) \text {, although presumably there is an } \\
\text { upper limit for frequency. } \\
\text { Feedback can sometimes be concurrent with the task (93) but most studies provided feedback more than one week later } \\
\text { (19). }\end{array}$ & $* * * *$ \\
\hline \multirow[t]{7}{*}{$\begin{array}{l}\text { 3. Goal- } \\
\text { setting }\end{array}$} & $\begin{array}{l}\text { 3.1 Presence or } \\
\text { absence of goal- } \\
\text { setting }\end{array}$ & Present, absent & $\begin{array}{l}\text { - The included papers suggested that knowing what to do with feedback is as important as receiving it (28). } \\
\text { - Some included empirical studies did not have a goal setting stage beyond feedback (31); for others, this was the main focus } \\
\text { (88). } \\
\text { - } \quad \text { Feedback is thought to be more effective when combined with reflection and/or goals and an action plan }(3,5,18,19) \text {. } \\
\text { - } \text { hard to interpret (5). }\end{array}$ & $* * * *$ \\
\hline & $\begin{array}{l}\text { 3.2 Presence of a } \\
\text { reviewer to } \\
\text { support goal- } \\
\text { setting }\end{array}$ & Present, absent & $\begin{array}{l}\text { - Most included studies involved a reviewer in goal-setting (29): few studies involved goal setting without support. } \\
\text { - This may reflect implicit theories about the need for support in this step, although many studies also conflated feedback and } \\
\text { goal-setting and the reviewer's primary role was often unclear. }\end{array}$ & $* *$ \\
\hline & $\begin{array}{l}\text { 3.3 Relationship } \\
\text { to reviewer }\end{array}$ & $\begin{array}{l}\text { Senior } \\
\text { colleague/supervi } \\
\text { sor, peer, external } \\
\text { person }\end{array}$ & $\begin{array}{l}\text { - The reviewer needed to be perceived as credible, which was often judged based on seniority }(3,4) \text {, although the evidence is } \\
\text { unclear (19), context familiarity ( } 30) \text { and facilitation skills }(29) \text {. } \\
\text { Goal-setting enabled reviewers to make their professional knowledge explicit through dialogue }(88) \text { but required personality } \\
\text { compatibility (29). }\end{array}$ & $* * *$ \\
\hline & 3.4 Nature of goal & $\begin{array}{l}\text { Clarity and degree } \\
\text { of challenge }\end{array}$ & - The reviewer should direct attention to task processes rather than metatask processes $(5,18)$. & * \\
\hline & $\begin{array}{l}\text { 3.5 Tailoring of } \\
\text { goal setting } \\
\text { conversation to } \\
\text { individuals }\end{array}$ & $\begin{array}{l}\text { Standardised } \\
\text { approach or } \\
\text { tailoring, tailoring } \\
\text { permissible }\end{array}$ & $\begin{array}{l}\text { - Feedback may not work in the same way for all recipients and/or settings, so tailoring is recommended }(19,88) \text {, which may } \\
\text { require prior knowledge. } \\
\text { - Reviewers often had to assess whether a professional behaviour was applicable to that practice scenario }(33) \text {. }\end{array}$ & ** \\
\hline & $\begin{array}{l}\text { 3.6 Nature of } \\
\text { conversation }\end{array}$ & $\begin{array}{l}\text { Supportive, } \\
\text { combination of } \\
\text { support and } \\
\text { challenge, } \\
\text { challenge only }\end{array}$ & $\begin{array}{l}\text { - According to FIT, in reacting to feedback, ECPs have several behavioural options e.g. strive to attain the goal, change the } \\
\text { goal, reject the feedback, or abandon commitment to the goal (5). } \\
\text { A quality goal-setting conversation can help learners to identify the gap between current and desired performance and } \\
\text { agree a strategy for change (88). } \\
\text { - Cues that foster high self-efficacy may direct attention back to the task and cause people to invest more effort (5). } \\
\text { - Some authors (88) assume that difficult, personal topics are discussed during goal-setting (e.g. commitment, attitude) but } \\
\text { this seems at odds with FIT (5), which advocates avoiding attention to meta-task. }\end{array}$ & * \\
\hline & $\begin{array}{l}\text { 3.7 Recipient } \\
\text { ownership of goal } \\
\text { setting }\end{array}$ & $\begin{array}{l}\text { Low, medium, } \\
\text { high }\end{array}$ & $\begin{array}{l}\text { - Involvement of recipients in the process of goal setting was thought important to maximise impact by some authors }(88,93) \\
\text { and make asymmetric power relations (which are probably inevitable where only one party's work is analysed) more } \\
\text { balanced (88). }\end{array}$ & * \\
\hline
\end{tabular}


This is the peer reviewed version of the following article: Mattick, K., Brennan, N. Briscoe, S. , Papoutsi, C. and Pearson, M. (2019), Optimising feedback for early career professionals: a scoping review and new framework. Med Educ, 53: 355-368, which has been published in final form at https://doi.org/10.1111/medu.13794. This article may be used for non-commercial purposes in accordance with Wiley Terms and Conditions for Use of Self-Archived Versions.

\begin{tabular}{|c|c|c|c|c|}
\hline & & - & Learning through discovery was theorised to be more powerful and sustainable than feedback from an external agent (5). & \\
\hline $\begin{array}{l}\text { 3.8 Acceptance of } \\
\text { goals suggested }\end{array}$ & $\begin{array}{l}\text { Complete } \\
\text { acceptance, } \\
\text { partial } \\
\text { acceptance, } \\
\text { rejection }\end{array}$ & & $\begin{array}{l}\text { Goals are unlikely to be accepted or prioritised if the immediate relevance to practice setting is unclear }(18,27,28,30,60, \\
88) \text {. } \\
\text { It seemed important for recipients to be able to discuss the performance context }(27,29) \text { since sometimes apparent 'poor } \\
\text { performance' was the most appropriate action/judgment when considered in context }(27,28) \text {. } \\
\text { Motivation for behavioural change may be secured by increasing participant's perceptions of best practice; and/or } \\
\text { increasing the standard of their typical practice ( } 28) \text {. } \\
\text { Acceptance of goals depended on whether they were seen as beyond the scope of responsibility or possibility of an ECP ( } 27 \text {, } \\
88) \text {. }\end{array}$ & $* *$ \\
\hline $\begin{array}{l}\text { 3.9 Successful } \\
\text { completion of } \\
\text { goals set }\end{array}$ & $\begin{array}{l}\text { Success, partial } \\
\text { success, failure }\end{array}$ & & $\begin{array}{l}\text { Successful completion of goals may depend on context and may be beyond the control of ECPs }(3,28,30) \text {, even if there is } \\
\text { strong intention to change behaviour. } \\
\text { Feedback on metrics over which ECPs have no behavioural control is likely to lead to disengagement (27). } \\
\text { Involvement of end users (e.g. patients/families) in feedback processes may help secure commitment to change (32). } \\
\text { Some mechanisms underpinning poor uptake/effectiveness of feedback interventions were complex and only picked up via } \\
\text { qualitative process evaluation ( } 28,30) \text {. } \\
\text { If working harder fails and they are still sufficiently motivated to do so, ECPs may reflect on the situation and reframe the } \\
\text { problem, leading to a new plan for improved performance (5). } \\
\text { Motivation to change targeted behaviour is relatively understudied (93). } \\
\text { When a Fl increases performance through an increase in task motivation the effect may depend on a continuous FI (5), } \\
\text { whereas for some other mechanisms a 'one off' Fl may be effective. }\end{array}$ & $*$ \\
\hline
\end{tabular}


This is the peer reviewed version of the following article: Mattick, K., Brennan, N. Briscoe, S. , Papoutsi, C. and Pearson, M. (2019), Optimising feedback for early career professionals: a scoping review and new framework. Med Educ, 53: 355-368, which has been published in final form at https://doi.org/10.1111/medu.13794. This article may be used for non-commercial purposes in accordance with Wiley Terms and Conditions for Use of Self-Archived Versions.

Table 6: Summary of the Feedback Framework, comparing FIT (5) and the new knowledge provided through our study with ECPs

\begin{tabular}{|c|c|c|}
\hline Category & What FIT says & What our study with ECPs adds \\
\hline 1. Audit & $\begin{array}{l}\text { Choosing the right measure is important. } \\
\text { If baseline performance is very low, then rapid improvement } \\
\text { is needed to sustain engagement with the task. } \\
\text { Feedback messages may be undermined by contextual cues. }\end{array}$ & $\begin{array}{l}\text { ECPs are more likely to have a low baseline performance and may be } \\
\text { disheartened more easily than more senior colleagues, without appropriate } \\
\text { support, so choice of measure is even more important for ECPs. } \\
\text { The relevant contextual cues probably differ for ECPs, especially given their dual } \\
\text { goals of training and practice, which may be in tension. }\end{array}$ \\
\hline $\begin{array}{l}\text { 2. Feedback } \\
\text { intervention }\end{array}$ & $\begin{array}{l}\text { Comparison to past performance and external standards, } \\
\text { and feedback on group performance, is likely to be } \\
\text { beneficial. } \\
\text { Praise and discouragement, face-to-face feedback, public } \\
\text { feedback and peer comparisons may well be detrimental. }\end{array}$ & $\begin{array}{l}\text { Past performance data may not exist for ECPs, clear expected standards may } \\
\text { not be available or known about, and support networks may not yet be in place, } \\
\text { so ECPs will need additional help to gain the most benefit from feedback. } \\
\text { ECPs may have less confidence in their abilities and be more alert to praise or } \\
\text { discouragement, so feedback must explicitly steer them back to task and avoid } \\
\text { affective reactions. }\end{array}$ \\
\hline $\begin{array}{l}\text { 3. Goal- } \\
\text { setting }\end{array}$ & $\begin{array}{l}\text { Feedback likely to be more effective when combined with } \\
\text { reflection and/or goals and an action plan, especially when } \\
\text { feedback information is hard to interpret or requires a } \\
\text { different way of working. } \\
\text { Cues that foster high self-efficacy may result in more effort. }\end{array}$ & $\begin{array}{l}\text { FIT does not place much emphasis on the goal-setting stage but this seems } \\
\text { critically important for ECPs. } \\
\text { ECPs are more likely to find feedback hard to interpret but are also more likely } \\
\text { to be open to different ways of working, since their habits are less long- } \\
\text { established. }\end{array}$ \\
\hline
\end{tabular}

